REPORTED WATER USE IN KANSAS, 1987

By Joan F. Kenny

U.S. GEOLOGICAL SURVEY

Open-File Report 91-212

Prepared in cooperation with the KANSAS STATE BOARD OF AGRICULTURE, DIVISION OF WATER RESOURCES 


\section{U.S. DEPARTMENT OF THE INTERIOR}

MANUEL LUJAN, JR., Secretary

U.S. GEOLOGICAL SURVEY

Dallas L. Peck, Director

For additional information write to:

Copies of this report can be purchased from:

District Chief

U.S. Geological Survey

Water Resources Division

4821 Quail Crest Place

Lawrence, Kansas 66049
U.S. Geological Survey

Books and Open-File Reports

Denver Federal Center, Bldg. 810

Box 25425

Denver, Colorado 80225 


\section{CONTENTS}

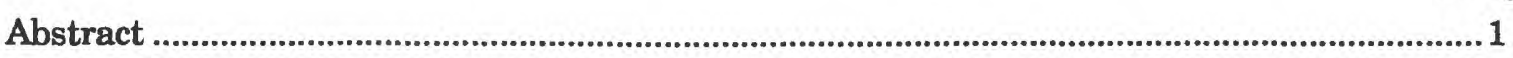

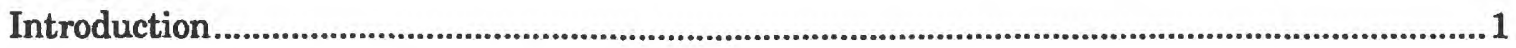

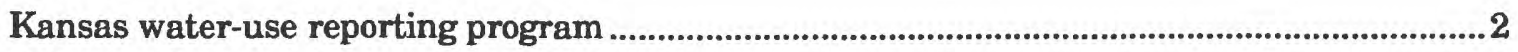

Geographic factors affecting water use ...................................................................

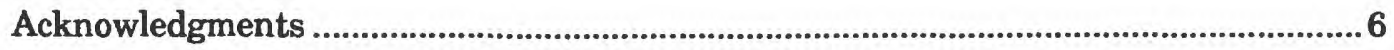

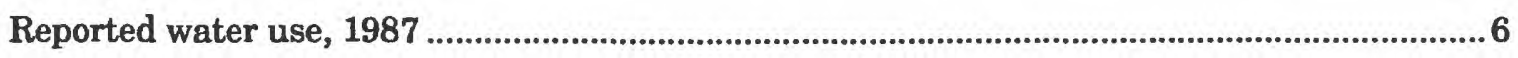

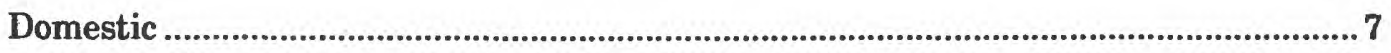

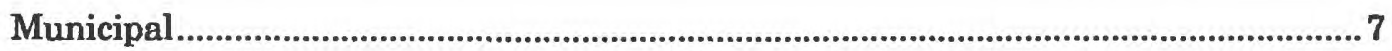

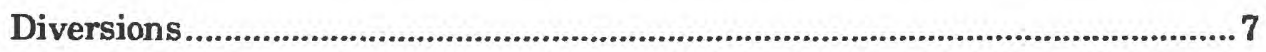

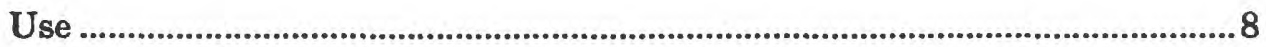

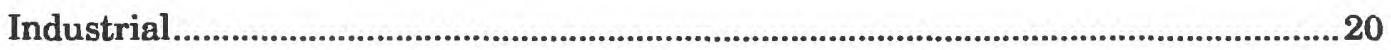

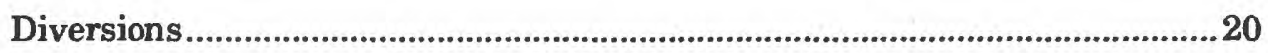

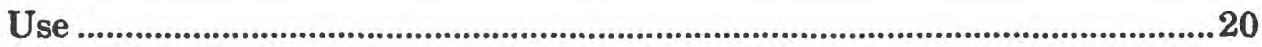

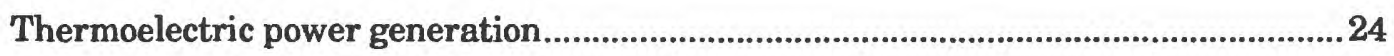

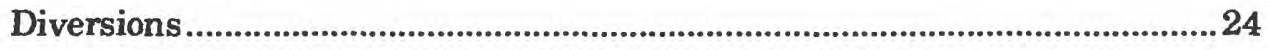

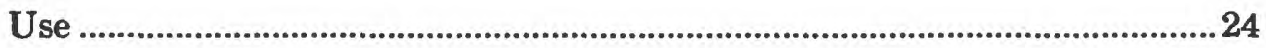

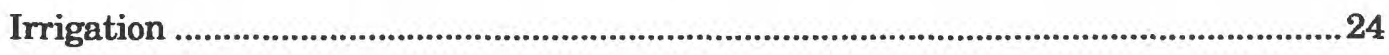

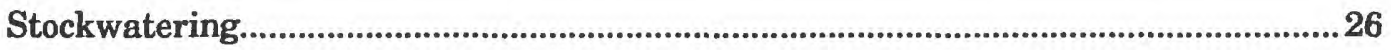

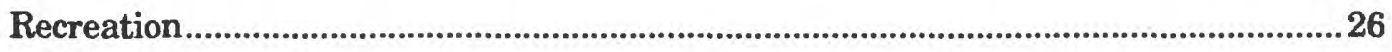

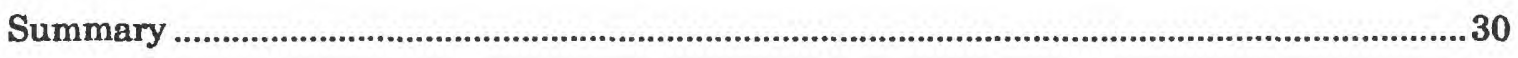

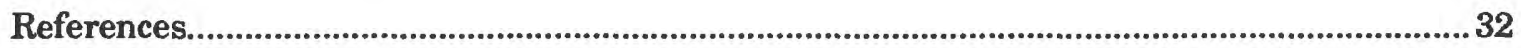




\section{CONTENTS--Continued}

Figure

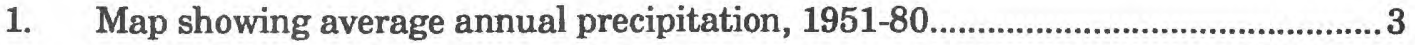

2. Map showing major aquifers in Kansas ........................................................... 4

3. Map showing major river basins in Kansas........................................................ 4

4. Map showing population in Kansas by county, 1987 ..........................................5

5. Diagram showing total reported water diversions by type of use, $1987 \ldots \ldots \ldots \ldots \ldots . . . .6$

6. Diagram showing reported water diversions for municipal use by source of supply, 1987

7. Map showing reported total water diversions for municipal use by county, 1987

8. Maps showing reported surface- and ground-water diversions for municipal

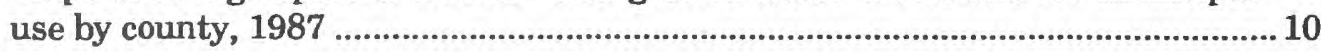

9. Diagram showing reported municipal water use by type of facility, $1987 \ldots . . . . . . .12$

10. Map showing reported water use by urban communities by county, 1987 ..........13

11. Map showing reported water purchased by urban communities by county, 1987

12. Maps showing reported water sold to other public suppliers and industry by urban communities by county, 1987

13. Map showing reported water use by rural water districts by county, $1987 \ldots \ldots . . .17$

14. Maps showing reported water use in gallons per capita per day for urban communities and rural water districts by county, 1987 .

15. Diagram showing reported water diversions for industrial use by source of supply, 1987

16. Map showing reported total water diversions for industry by county, 1987 21

17. Maps showing reported surface- and ground-water diversions for industry by county, 1987

18. Map showing reported water use for industry by county, 1987

19. Diagram showing reported water diversions for thermoelectric power generation by source of supply, 1987 .

20. Map showing reported total water diversions for thermoelectric power generation by county, 1987

21. Maps showing reported surface- and ground-water diversions for thermoelectric power generation by county, 1987 


\section{CONTENTS--Continued}

Figure

Page

22. Diagram showing consumptive and nonconsumptive water use for

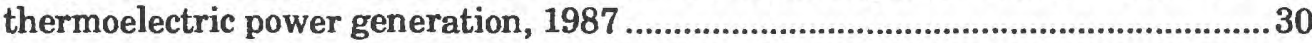

23. Map showing reported water use for thermoelectric power generation by

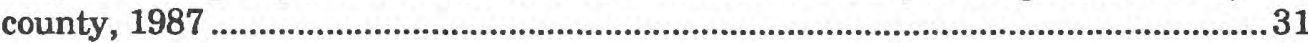

24. Diagram showing reported water diversions for irrigation by source of supply, 1987

25. Map showing reported total water diversions for irrigation by county, $1987 \ldots . . .33$

26. Maps showing reported surface- and ground-water diversions for irrigation by county, 1987 . 34

27. Diagram showing reported water diversions for stockwatering by source of supply, 1987 .36

28. Map showing reported total diversions for stockwatering by county, 1987 37

29. Diagram showing reported water diversions for recreation by source of supply, 1987 38

30. Map showing reported total water diversions for recreation by county, 1987 39

\section{CONVERSION FACTORS}

\section{Multiply}

inch

mile

acre

gallon

million gallons (Mgal)

acre-foot
By

1.609

4,047

3.785

3,785

1,233
To obtain

centimeter

kilometer

square meter

liter

cubic meter

cubic meter 
vi REPORTED WATER USE IN KANSAS, 1987 


\title{
REPORTED WATER USE IN KANSAS, 1987
}

\author{
By Joan F. Kenny
}

\section{ABSTRACT}

Water-use reports are required annually by the Kansas State Board of Agriculture, Division of Water Resources, for all permitted water diversions. Data included on the reports are surface- and ground-water diversions for domestic, municipal, industrial, thermoelectric power generation, irrigation, stockwatering, and recreation uses. Data collected on municipal, industrial, and thermoelectric-power-generation water-use reports also include quantities of water purchased and sold, which allows evaluation of both water diverted and water used.

For 1987, a total diversion of $1,760,658$ million gallons (5.4 million acre-feet) of water was reported to the Division of Water Resources for all types of use. Ground water supplied 81 percent of this total. Reported diversions for domestic, industrial, irrigation, and stockwatering uses were primarily from ground-water sources. Reported diversions for thermoelectric power generation and recreation were primarily from surface-water sources. Most of the water diverted for power generation was used nonconsumptively. Reported diversions for municipal use were withdrawn equally from surface- and ground-water sources. More water was used for municipal supplies in the populous eastern part of Kansas, but water use in gallons per capita per day was greater in the arid western part of the State.

In 1987 , a reported $1,403,122$ million gallons of water were diverted for irrigation, primarily in the western and central parts of the State that are underlain by major aquifers. Diversions for irrigation represented 80 percent of the total diversions, making this type of water use the largest in Kansas.

\section{INTRODUCTION}

This report documents reported water use in Kansas for 1987. Regulation of water use in Kansas is the responsibility of the Kansas State Board of Agriculture, Division of Water Resources (DWR). Like most western States,
Kansas has a prior appropriations doctrine for managing its water resources. This doctrine became law with the Kansas Water Appropriation Act of 1945, which recognized that all water in the State belongs to the people, to be appropriated for beneficial uses. In 1987, there were eight beneficial uses for which a water right could be obtained: domestic, industrial, irrigation, municipal, recreation, stockwatering, water power, and artificial recharge. Water power refers to hydroelectric power generation. Thermoelectric power generation is considered an industrial use by the DWR.

Water rights are granted for both surfaceand ground-water diversions. The term "diversion" applies to water from streams, lakes, wells, or springs in which the natural flow is altered by an appropriator and put to beneficial use.

Two types of water rights have been issued by the DWR. Vested rights are those issued to water users for water diversions occurring prior to 1945 and are superior to all other rights. Appropriation rights are issued to applicants filing an application with the Chief Engineer, DWR, to appropriate water for beneficial use. The priority of a water right is determined by the date of filing.

As of 1988 , there were about 29,000 active water rights in Kansas, representing some 35,000 points of diversion. In 1987 , about 86 percent of the diversion points were for irrigation water use, about 7 percent for municipal use, 4 percent for industrial use, and about 1 percent each for stockwatering and recreation use. Less than 1 percent of all legal diversion points were for domestic water use because permits are not required for this category. There was only one water right for hydroelectric power generation in Kansas in 1987, and one for artificial recharge.

As part of a cooperative program with the DWR, the U.S. Geological Survey (USGS) 
summarizes water-use data from the State to meet local and National information needs. These data exist as part of the DWR's administrative system for managing water rights and do not always correspond to wateruse categories established by the USGS to estimate total water use in each State for the National Water-Use Information Program (see Solley and others, 1988). For example, the DWR's domestic category includes rural selfsupplied water use for both humans and livestock. The USGS domestic category includes self-supplied withdrawals and public-supply deliveries for household use. The DWR's stockwatering category applies only to large feedlot operations; the USGS livestock category includes both large- and small-scale stock water use. Industrial, mining, thermoelectric power generation, and some commercial water uses are included in the DWR's industrial category but are separate categories in the USGS's National Water-Use Information Program. These differences in terminology result from the respective approaches to water-use data by the two agencies and should not impair the usefulness of the data presented in this report.

\section{Kansas Water-Use Reporting Program}

The water-use reporting program in Kansas has evolved during the years since the Water Appropriation Act of 1945 was passed. Several pieces of legislation established the procedure for reporting. In 1957, water-right owners were required to maintain records and annually report their water use or reason for non-use to the DWR. Report forms for this purpose were provided the following year. In 1978, a major amendment to the Water Appropriations Act made it mandatory to obtain a permit from the Chief Engineer of the DWR prior to diverting water for any type of use except domestic (although domestic water rights may be issued to those who wish to establish a legal right to divert water). As a result, the number of permits to appropriate water increased greatly after this amendment, and many more water rights were subject to the annual reporting law. During the early 1980 's, the DWR began to computerize water-use records, an effort that has facilitated enforcement of the reporting requirement and allowed greater use of the data. In 1986, waterright holders were asked to file their water-use reports within 30 days of receiving the forms. This requirement was strengthened in 1989 with a law imposing fines for late reporting, nonreporting, or falsified reporting. Currently (1991), the law indicates that all water-use reports must be filed in the office of the Chief Engineer no later than March 1 following the end of the previous calender year.

The type and quantity of information requested on water-use reports also has evolved. Original report forms were nonspecific for type of use and collected only minimal information about the water used at each point of diversion. Current water-use report forms are designed for domestic, municipal, industrial, irrigation, stockwatering, and recreation uses. Powergeneration and artificial-recharge uses are reported on industrial forms. Information required on all types of reports includes the metered quantity of water diverted during the previous calendar year, the hours pumped and estimated pump rate if the diverted quantity is not metered, water-level data for wells, and name and telephone number of the person responsible for filing the report. Additional information about numbers of people and livestock using the water, and acres of lawn and garden watered, is requested on domestic forms. Municipal and industrial forms require monthly accounts of water diverted, purchased from other sources, sold to other entities, and net amounts used by the industry or community holding the right. These reports also include spaces to record wastewater discharges and method of disposal. In addition, municipal water-use forms require estimates of population served and number of connections for the community diverting water. Irrigation wateruse reports provide spaces to record acres irrigated by each water right and to indicate if chemigation is planned for those acreages. Average numbers of cattle and hogs watered throughout the year are required on stockwatering forms. Recreation water-use reports request information on reservoir stage during the past year if diversions are from ponds or lakes.

Increased efforts to collect water-use data have been paralleled by increased attention to the quality of data processed and stored. Reviewing of reports as they are returned to the DWR allows enforcement of the laws requiring 
timely and accurate reports and improves the usefulness of the data for assessing water use in Kansas. The Kansas Water Office, the waterplanning and policy agency for the State, assists in the reviewing of water-use reports and analysis of the data. Water-use report forms for a given year are mailed to water-use correspondents (the individuals responsible for completing the forms) in January of the following year and are returned with varying degrees of promptness. Processing typically requires staff resources throughout the year and consists of an ongoing series of manual and computer checks, data entry and proofreading, ownership and address changes, telephone calls, follow-up mailings, filing, and, in some cases, legal action. Water-use data for any year may be updated with the arrival of an amended report for that year, so total reported water use is always subject to change. However, reported water-use data for a given year usually are available by the end of the following year.

\section{Geographic Factors Affecting Water Use}

Water use in Kansas follows general climatic, physiographic, and demographic patterns (see Kenny, 1986). The information in this section of the report is provided as a reference for discussions of reported water use for the various categories of use.

Water availability, a primary determinant of water use, is unevenly distributed throughout Kansas. Average annual precipitation ranges from less than 16 inches in the southwestern part of the State to more than 40 inches in the southeast (fig. 1). Major aquifers are shown in figure 2. Those yielding the largest amounts of water are the High Plains and Great Plains aquifers in central and western Kansas, the Kansas River alluvium in northeast Kansas, and the Ozark aquifer in extreme southeast Kansas (Bevans and others, 1985). Major river basins are shown in figure 3 . The most dependable streamflows prevail in the eastern part of the State from streams in the Kansas River basin (Jordan, 1986).

The population of Kansas in 1987 was 2,476,000 (Institute for Public Policy and Business Research, 1990). Population distribution by county is shown in figure 4 . The greatest number of people reside in the northeastern part of the State along the Kansas River, from Salina to Kansas City, and in south-

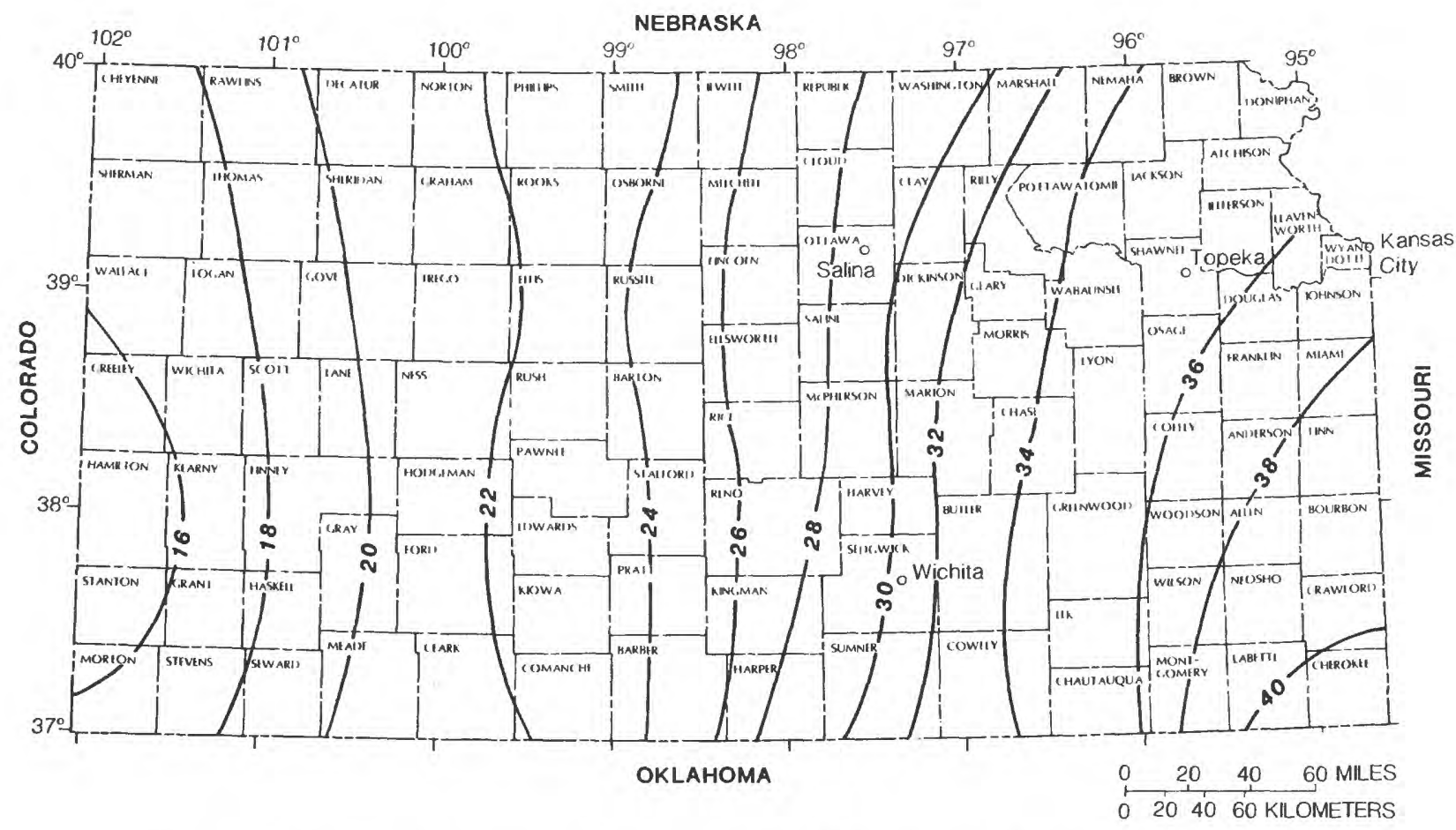

Figure 1. Average annual precipitation, 1951-80 (from Kansas Water Office, 1984). 


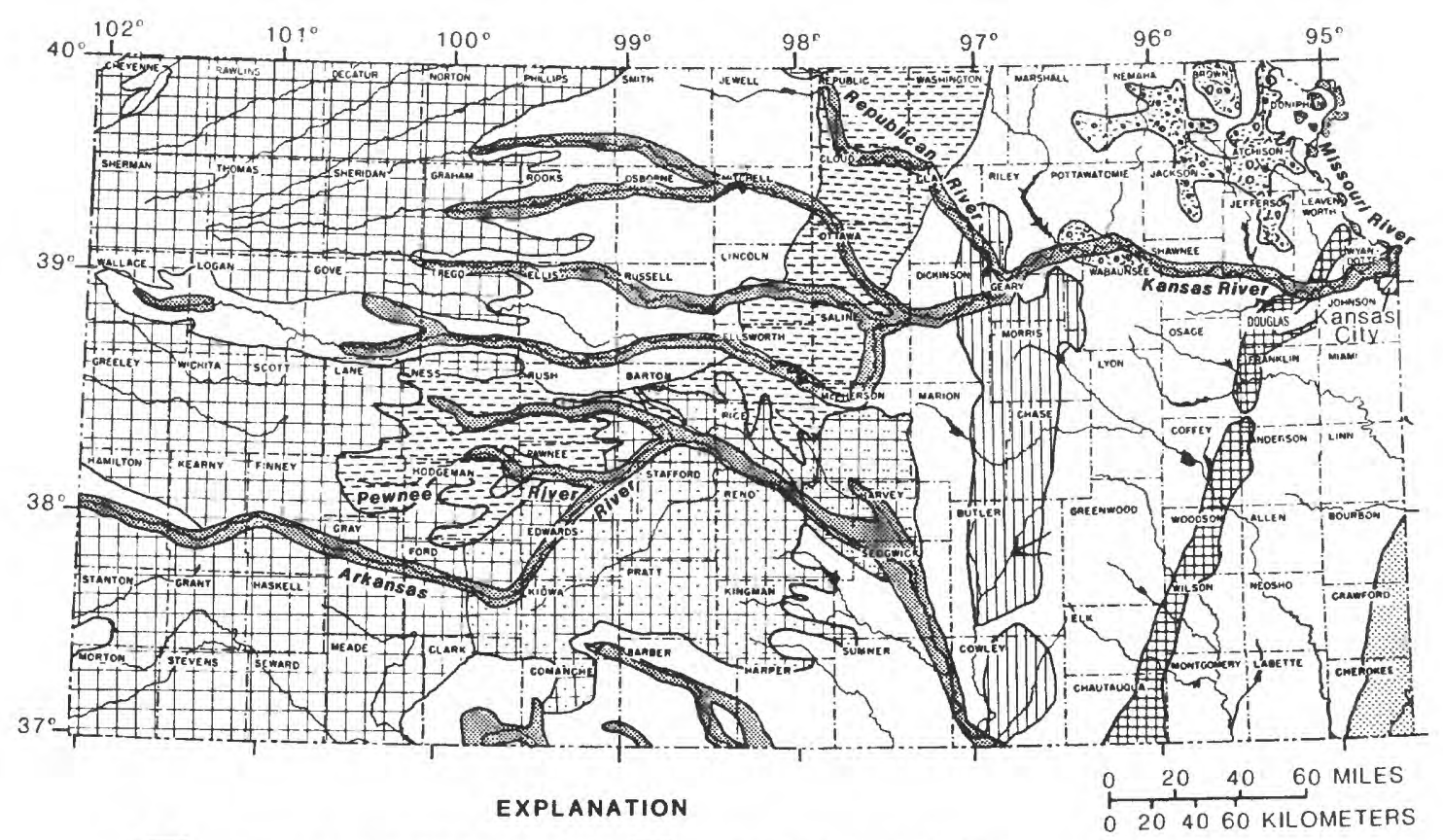

ALLUVIAL AQUIFERS
GLACIAL-DRIFT AQUIFER PLAINS AQUIFER
Gigut Bend Prairie aquifer

GREAT PLAINS AQUIFER

IIII CHASE AND COUNCIL GROVE AQUIFER

DOUGLAS AQUifER

OZARK AQUIFER

NOT A PRINCIPAL AQUIFER

Figure 2. Major aquifers in Kansas (modified from Bevans and others, 1985).

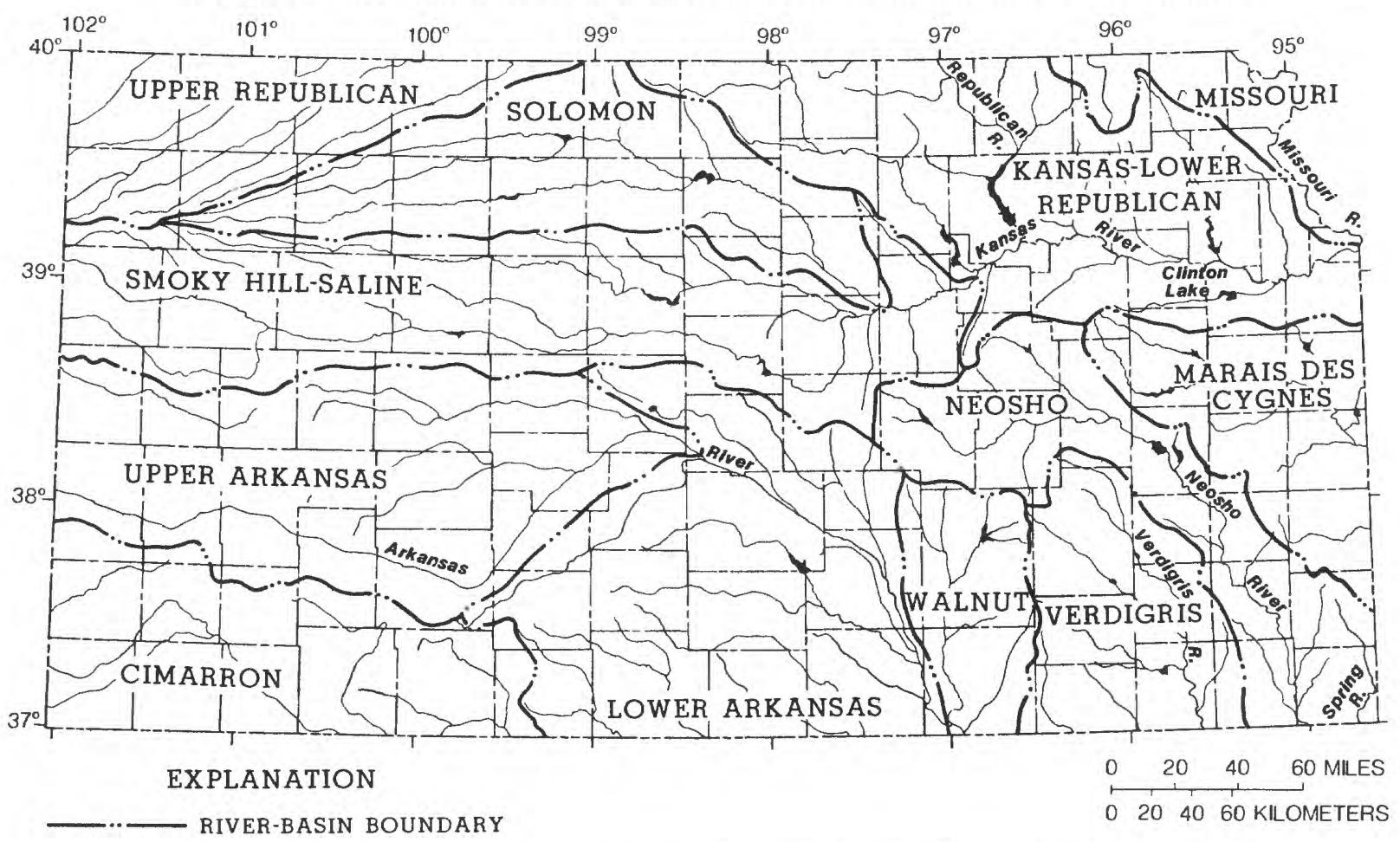

Figure 3. Major river basins in Kansas (modified from U.S. Geological Survey, 1976). 


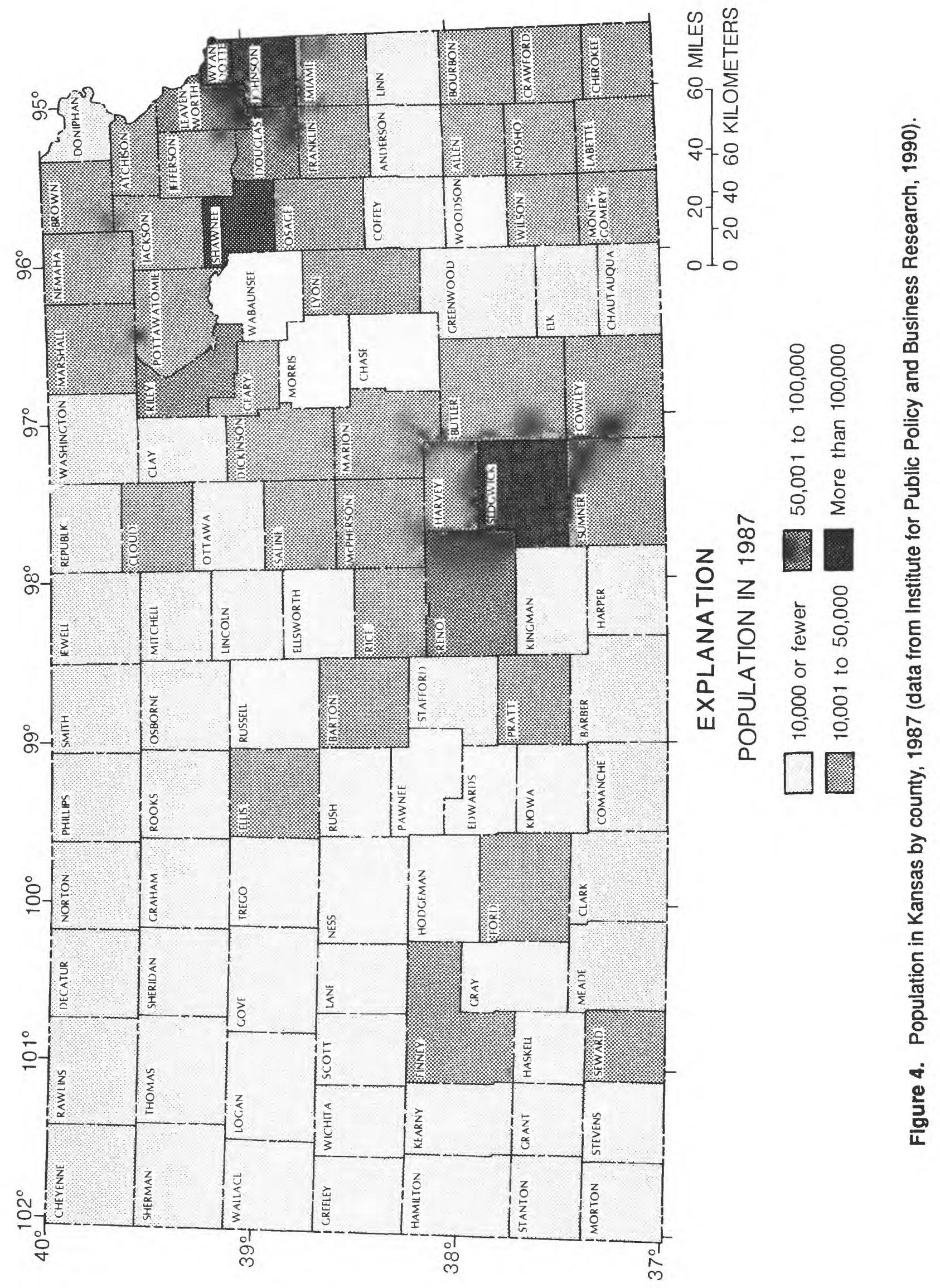


central Kansas around Wichita, the largest city in the State. The most populous counties are also those where business, industry, and manufacturing are concentrated. Water is used in these areas primarily for municipal and industrial purposes. The more sparsely populated counties are those in which agriculture is predominant. In the drier parts of the State, particularly western Kansas, irrigation is the largest water use.

\section{Acknowledgments}

The author wishes to acknowledge the assistance of Darrel Eklund and Cheryl Buttenhoff of the Kansas Water Office, who provided detailed water-use information on municipal and industrial users. These data were invaluable in preparing the summaries and diagrams for this report.

\section{REPORTED WATER USE, 1987}

For annual reporting of water use, water rights are grouped according to water-use correspondent, or person responsible for filing the report. Each water-use correspondent represents an individual or community that uses water, usually from more than one point of diversion. Of the 13,574 reports mailed in January 1988 pertaining to water used in 1987 , approximately 96 percent were returned to DWR. Reported diversions for all types of use totalled 1,760,658 Mgal (million gallons) in 1987. Of this amount, 81 percent was supplied by ground water and 19 percent by surface water.

The quantity and percentage of water diverted for the various categories of use are illustrated in figure 5. Reported diversions for the artificial-recharge category are included with industrial use. Withdrawals for thermoelectric power generation, considered industrial use in the Kansas water rights and water-use reporting system, are shown separately in this diagram and regarded as a distinct category throughout the remainder of this report. The water-power category is not shown in the diagram because the one hydroelectric plant in the State does not consumptively use water.

That part of water diversions that is evaporated, transpired, incorporated into products or crops, consumed by humans or livestock, or otherwise removed from the immediate water environment is called

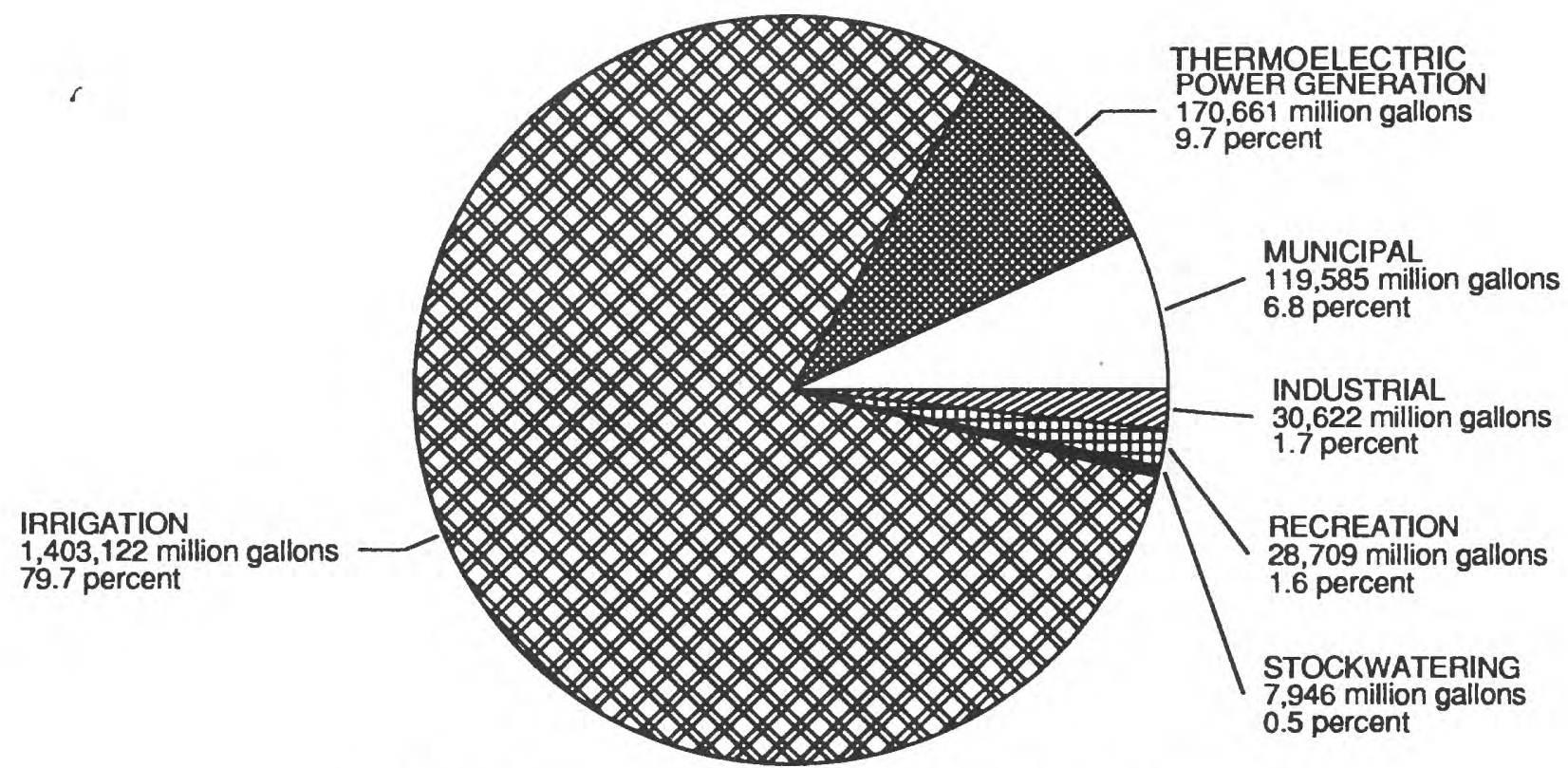

NOTE: A total of 13.6 million gallons of water reported for domestic use in 1987 is not shown in diagram.

Figure 5. Total reported water diversions by type of use, 1987. 
consumptive use (Solley and others, 1988, p. v). Nonconsumptive use is that part of the water withdrawn that is returned to the hydrologic environment. Most diversions involve some degree of both consumptive and nonconsumptive use although this distinction is not required on Kansas water-use report forms. Nonconsumptive water use is most significant in the power-generation category. Because water used to generate hydroelectric power flows through the turbines and down the river unchanged (flow-through), it is virtually all nonconsumptive. Water use for thermoelectric power generation also is largely nonconsumptive due to flow-through in rivers.

Information collected on the municipal and industrial report forms includes additional data on water purchases and sales and thus allows evaluation not only of water diversions but also of water use. Diversions are the quantities of raw water withdrawn from streams, lakes, or wells by the entity with the water right to make such withdrawals. Sometimes supplemented by additional purchased water, these diversions then are used for the municipal or industrial needs of the water-right holder; some of the water may be sold to other public suppliers or to industries. Water used by an entity with a water right is thus the sum of the quantities diverted and purchased minus the quantities sold, and may not be equal to the water diverted by that entity according to the water right.

\section{Domestic}

Diversion of water for self-supplied domestic use does not require a permit according to Kansas law, so only a small proportion of domestic users have obtained permits and report diversions. In 1987, those who held domestic water rights filed water-use reports totalling $13.6 \mathrm{Mgal}$. This quantity represents less than 0.1 percent of the self-supplied domestic withdrawals in 1985 estimated for Kansas by Solley and others (1988). Water rights for domestic use were held primarily by rural Kansans in 22 counties. About 77 percent (10.4 Mgal) of the reported water withdrawn was from ground-water sources; the remaining 23 percent (3.2 Mgal) was from surface water.

\section{Municipal}

\section{Diversions}

Water users with municipal water rights include many different types of entities that divert water for human needs. The DWR defines municipal use as "****the various uses made of water delivered through a common distribution system operated by a municipality, a rural water district, public wholesale water supply district, a group of householders, mobile home parks, or any other similar entity distributing water to other water users for household purposes***" [KSBA-DWR, 1983, sec. 5-1-1(p)]. These diversions represent raw water withdrawn for treatment and distribution by public watersupply systems and do not include purchases made in addition to quantities diverted according to the water right. Ultimately the water is used, within the community withdrawing the water or within communitites purchasing water, for urban and rural households, commercial businesses, industry that is supplied by public-water systems, and public-use sectors, such as firefighting, municipal parks and swimming pools, and water and wastewater-treatment plants.

Reported quantities of water withdrawn by right for municipal use during 1987 totaled $119,585 \mathrm{Mgal}$ (fig. 5). Approximately equal quantities of surface and ground water were diverted (fig. 6). Total reported diversions for municipal use are shown in figure 7 by the counties where the withdrawals occurred. Reported diversions from surface- and groundwater sources are shown by county in figure 8 . Surface-water diversions for municipal use occurred in 44 counties, mostly in the eastern part of the State (fig. 8A). In many of these counties, well yields are small, and there are few if any ground-water diversions for municipal use. Of the 101 water users reporting surfacewater withdrawals in 1987, 81 diverted no additional supply from ground water. Elsewhere, ground water supplies some or all of the water diverted by municipal water-right holders. A total of 543 water users in 98 counties reported ground-water withdrawals in 1987 (fig. $8 B) ; 523$ of these users diverted no surface 


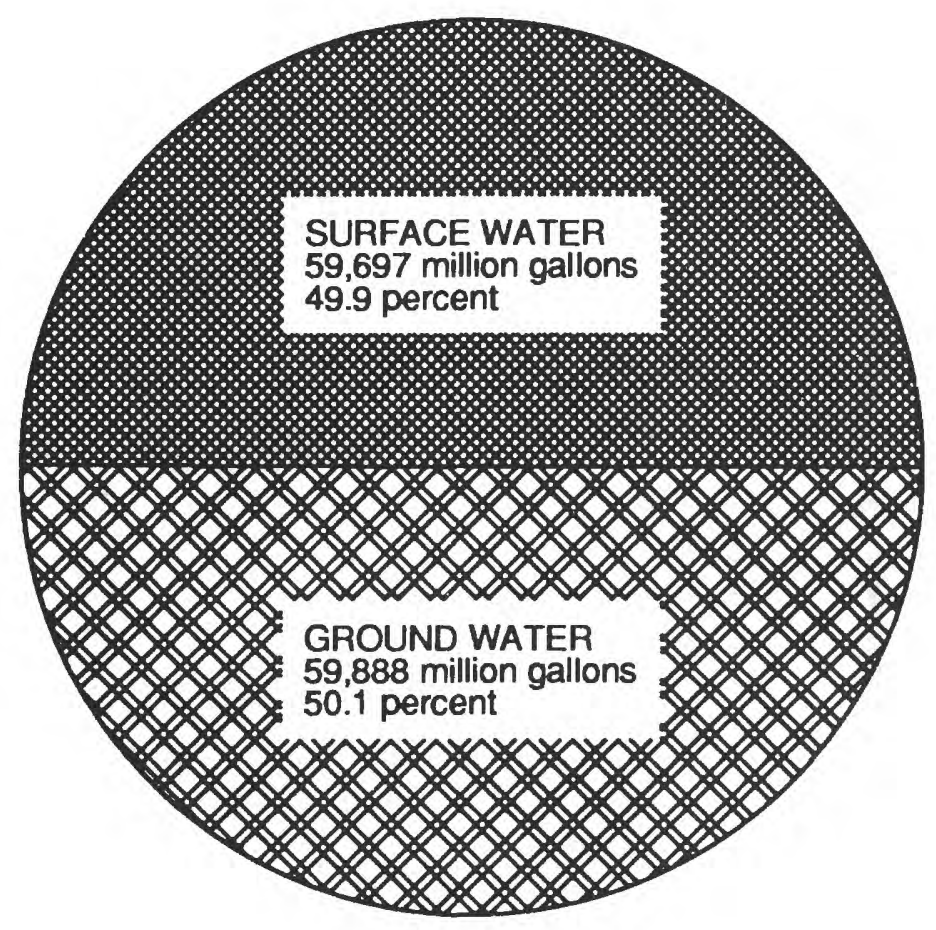

Figure 6. Reported water diversions for municipal use by source of supply, 1987.

water.

\section{Use}

Municipal water use reported to the DWR represents amounts used by municipal waterright holders for residential, commercial, and public uses, plus system losses. Water use is calculated as the sum of water diverted and water purchased minus water sold. Purchases recorded on annual water-use reports include those from other water-right holders and those from State-owned storage in Federal reservoirs. Purchases from reservoir storage are managed by the Kansas Water Office (KWO) through the Water Marketing Program, and totaled 1,963 Mgal in 1987. Sales recorded on water-use reports include those to other communities and to industries that use more than $1 \mathrm{Mgal}$ annually. Because of water sales and purchases, the quantity of water diverted by a municipal water-right holder does not necessarily correspond to the quantity used by the population served by that entity. In addition, the location of a water diversion is not necessarily the location of its use. Water may be withdrawn in one county and used in another, as when a city's water supply is a well field or lake in a neighboring county. This is the case in Sedgwick County, where the city of Wichita derives about 60 percent of its water from wells in Harvey County.

For purposes of data presentation in this report, the municipal category was divided into three types of facilities based on water-use characteristics of the populations served and the availability of population figures: (1) urban communities, (2) rural water districts, and (3) other facilities, such as prisons, hospitals, schools, camps, churches, and recreation areas. Of the total amount of water reported used by municipal water users in 1987 , the majority was for urban communities, those for which the population served resides in a city, town, suburb, or mobile-home park. The distribution of reported water use among urban communities, rural water districts, and other facilities is illustrated in figure 9.

Reported water use by urban communities with water rights totaled $100,394 \mathrm{Mgal}$ in 1987 (fig. 9) and is shown by county of use in figure 10. The largest amounts of water were used in 


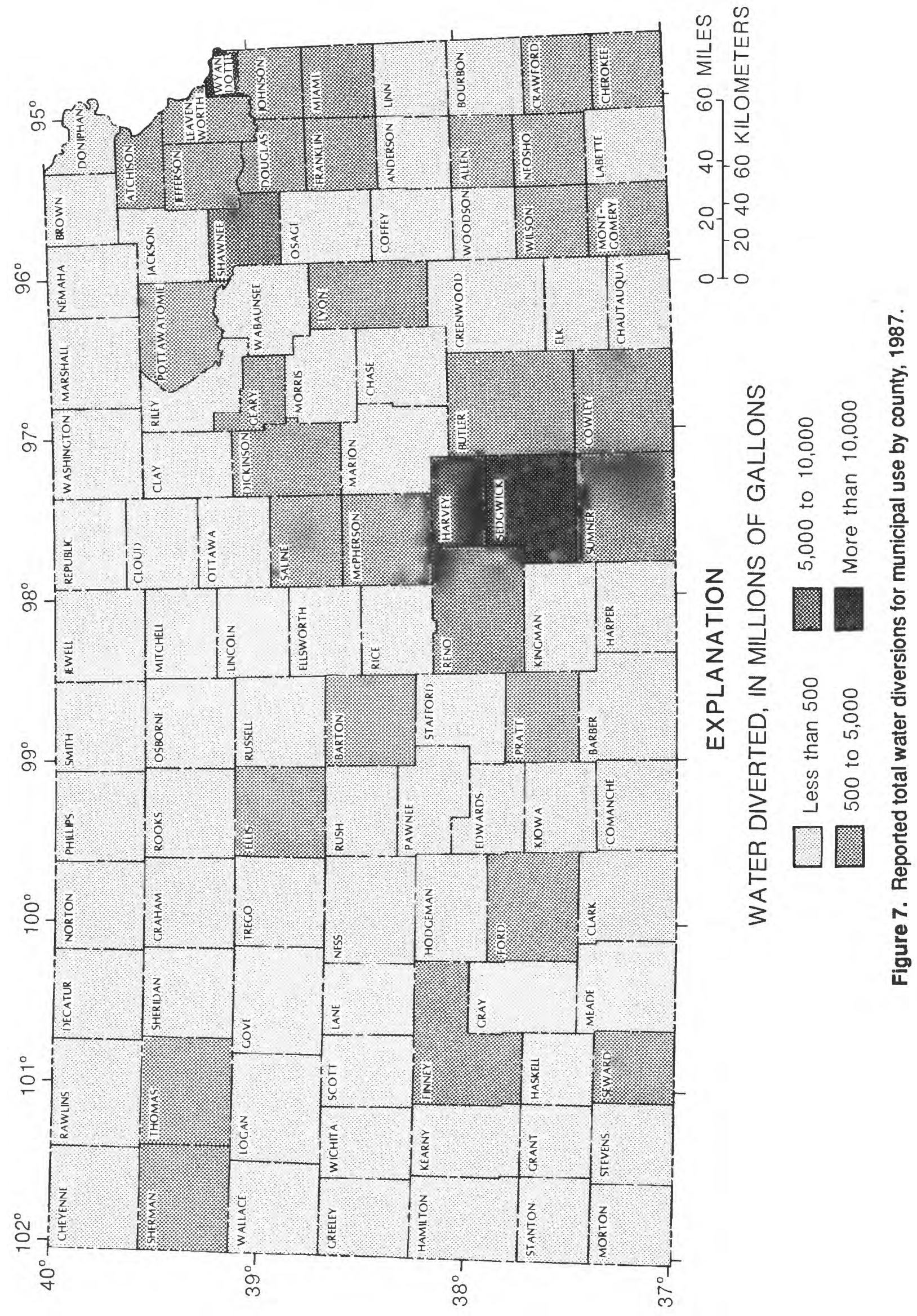




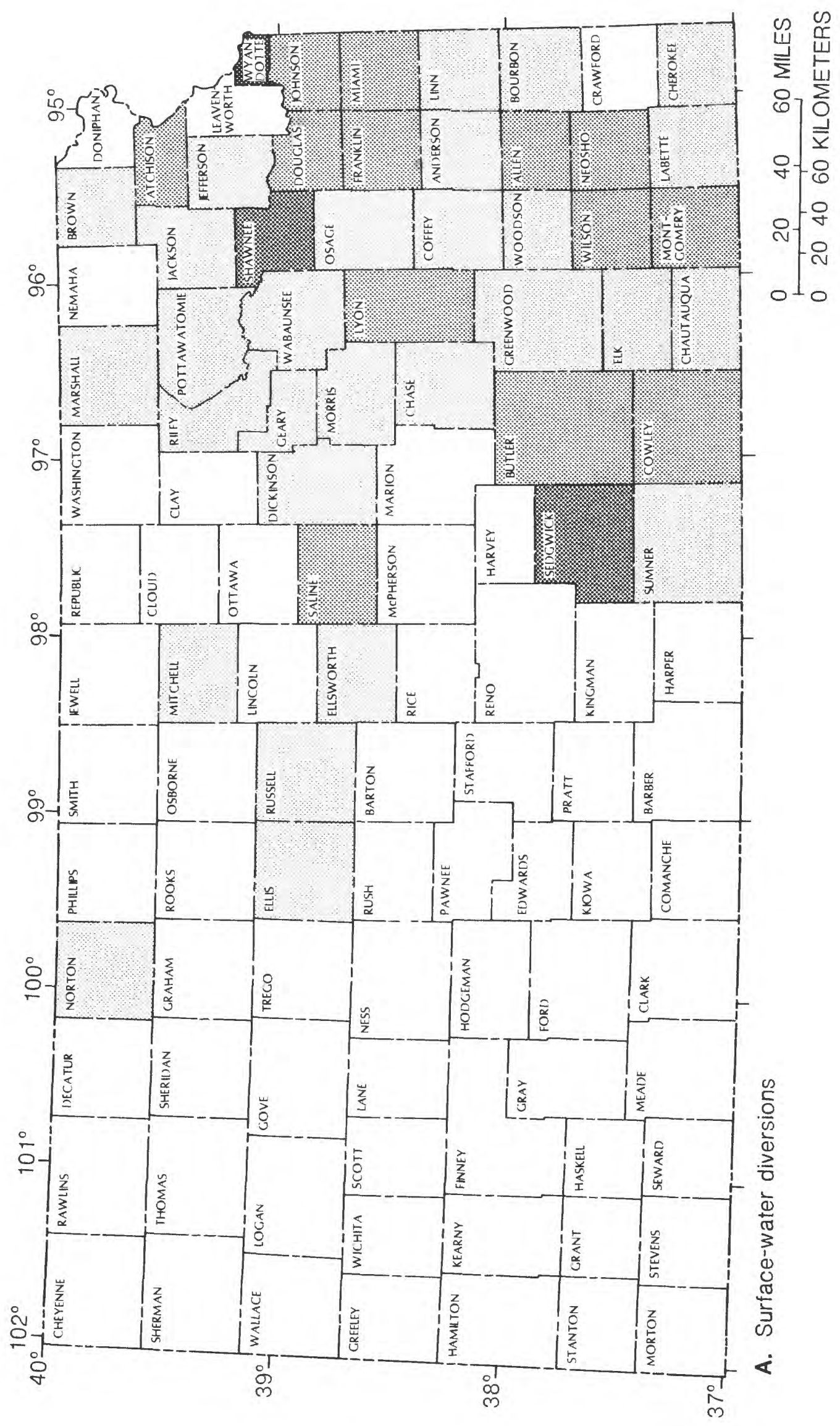

10 REPORTED WATER USE IN KANSAS, 1987 


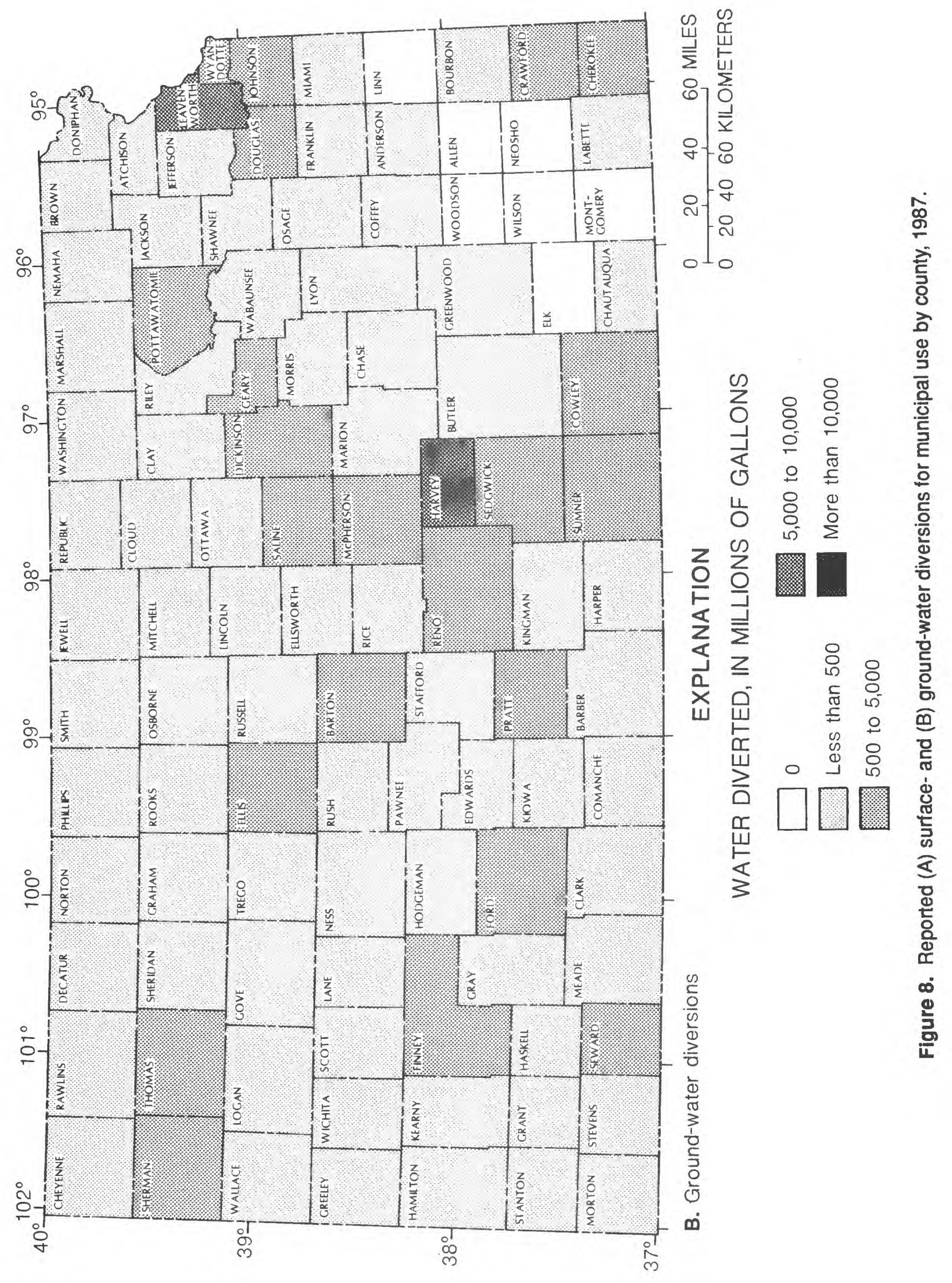




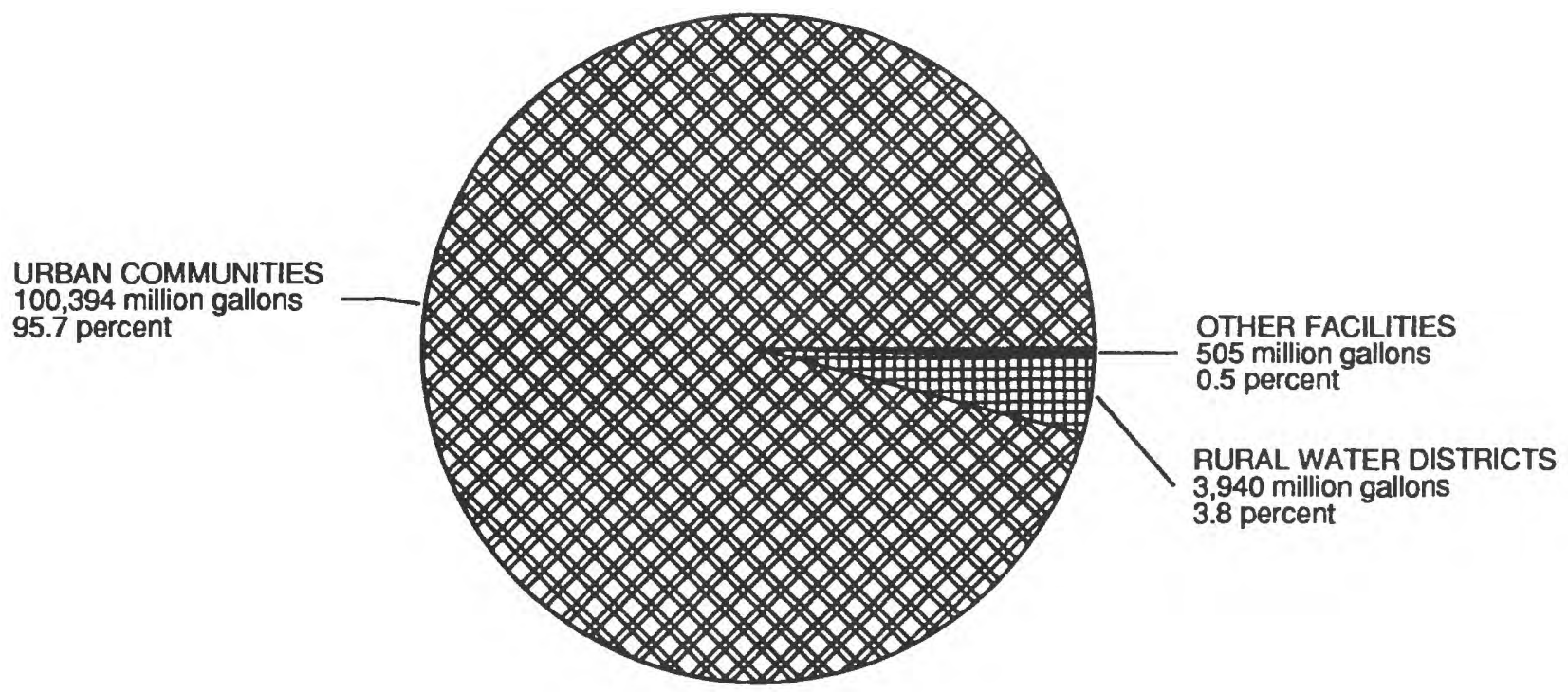

Figure 9. Reported municipal water use by type of facility, 1987.

Johnson, Sedgwick, Shawnee, and Wyandotte Counties, where the largest populations reside. About 3,050 Mgal of water were reported purchased in 1987 by urban communities with water rights; these amounts are shown by county in figure 11. Users in Douglas County bought the largest amount of water of any county in 1987 (1,528 Mgal), most of it through contracts with the KWO for water from Clinton Lake (fig. 3). Reported water sold in 1987 by urban communities with water rights to other cities, communities, or rural water districts totalled 4,798 $\mathrm{Mgal}$ and is shown in figure 12A by county of the origin of the sale. Because many cities provide water to smaller towns and rural water districts that have no convenient source of supply, sales of water were more common in the eastern counties where rural water districts are most numerous and ground water yields are generally small. Urban communities with water rights reported that $13,929 \mathrm{Mgal}$ of water were sold to industries using more than $1 \mathrm{Mgal}$ per year in 1987. These amounts are shown in figure 12B by county of the origin of the sale. Sales of water to large industries were more common in the counties with large populations.

Water use by rural water districts with water rights totaled $3,940 \mathrm{Mgal}$ in 1987 and is shown in figure 13 by county which organized the district. This amount includes 1,219 Mgal purchased from other suppliers. Many rural water districts serve customers in several different counties, but no records are maintained on the quantities of water used in each component county. Most of the water used by these districts was supplied to customers for domestic use and watering of lawns, gardens, and livestock. Water sold to other public suppliers by rural water districts, $468 \mathrm{Mgal}$ in 1987 , was mostly to other districts. Only about $40 \mathrm{Mgal}$ of water were supplied by rural water districts to major industries in 1987.

The remainder of municipal water-right holders, those facilities for which population figures are not available or relevant, reported water use in 1987 of about $505 \mathrm{Mgal}$ (fig. 9). About $52 \mathrm{Mgal}$ were bought from other suppliers, and $4 \mathrm{Mgal}$ were sold to other entities. No water was sold to industry by these users.

Water use expressed as a rate, such as gallons per capita per day (gpcd), is useful for comparing water use in different areas of the State independently of population sizes. Gpcd rates for urban communities and rural water districts are shown in figure 14. In general, counties in eastern Kansas use less water per capita for municipal uses than the more arid counties of western Kansas (see Kansas Water Office and Kansas State Board of Agriculture, Division of Water Resources, 1988).

Figures for population served by municipal water-right holders are essential for computation of gped values, yet often they are not reported with great certainty by the wateruse correspondents. Values for gped in figure 14 


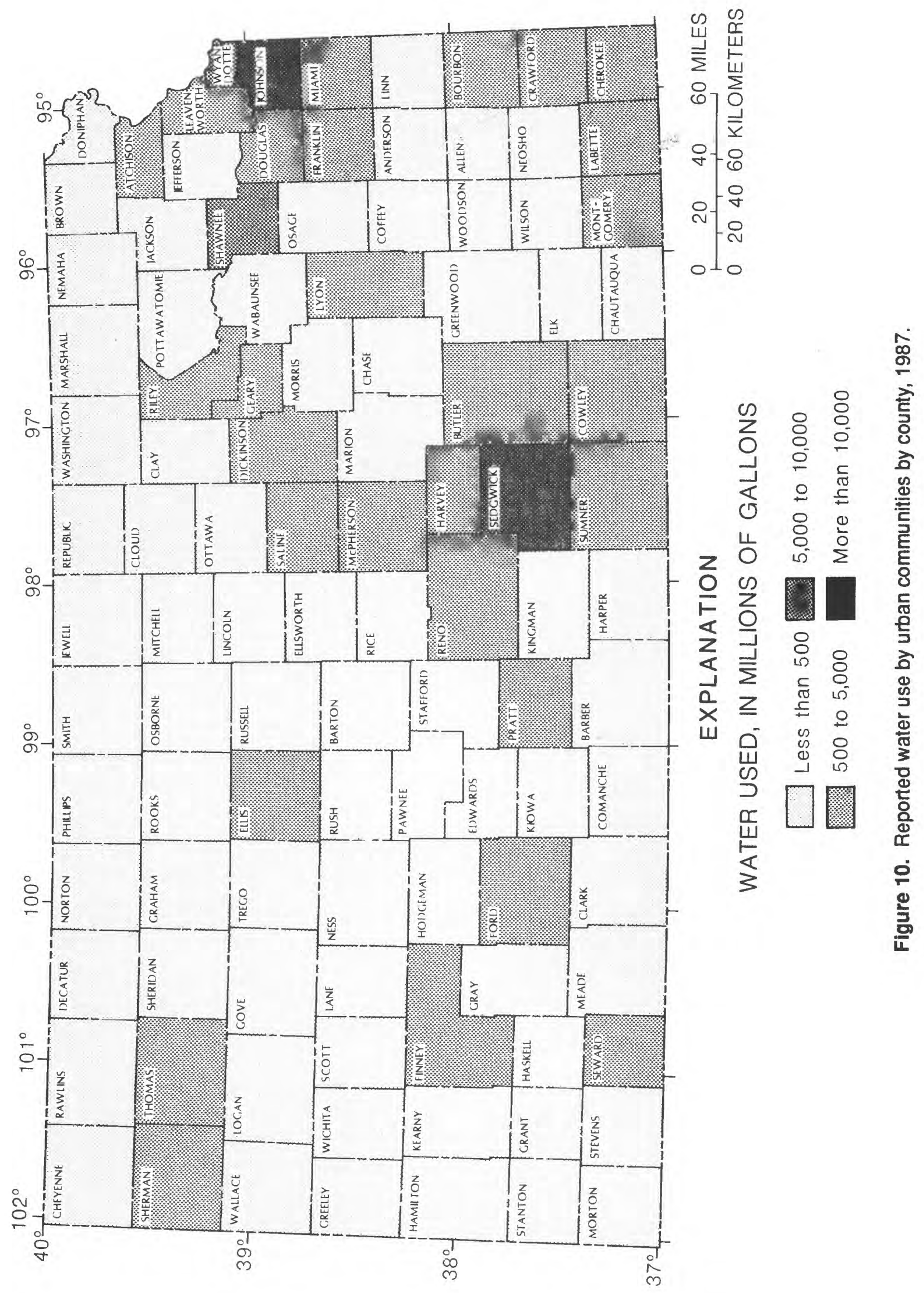




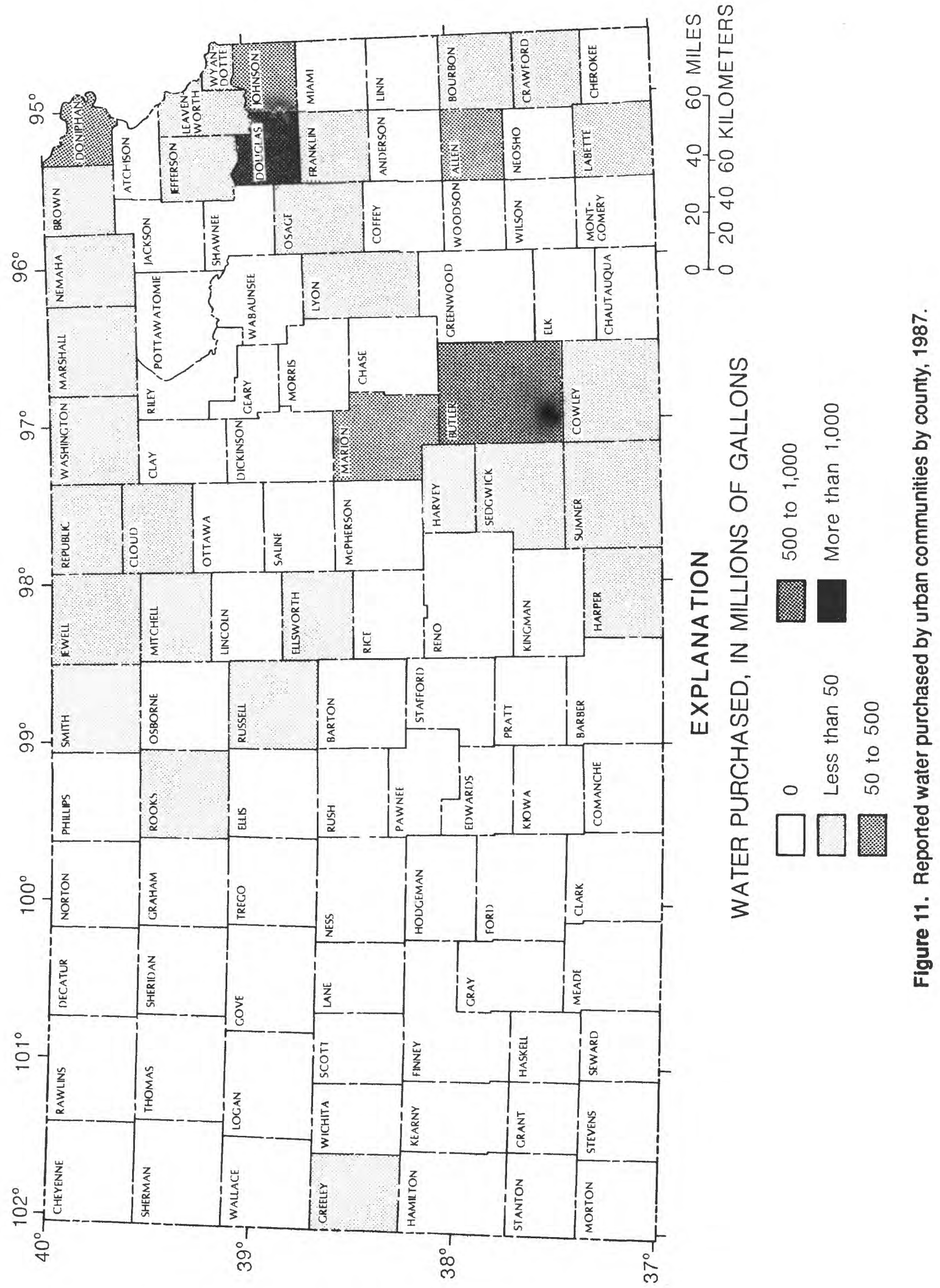




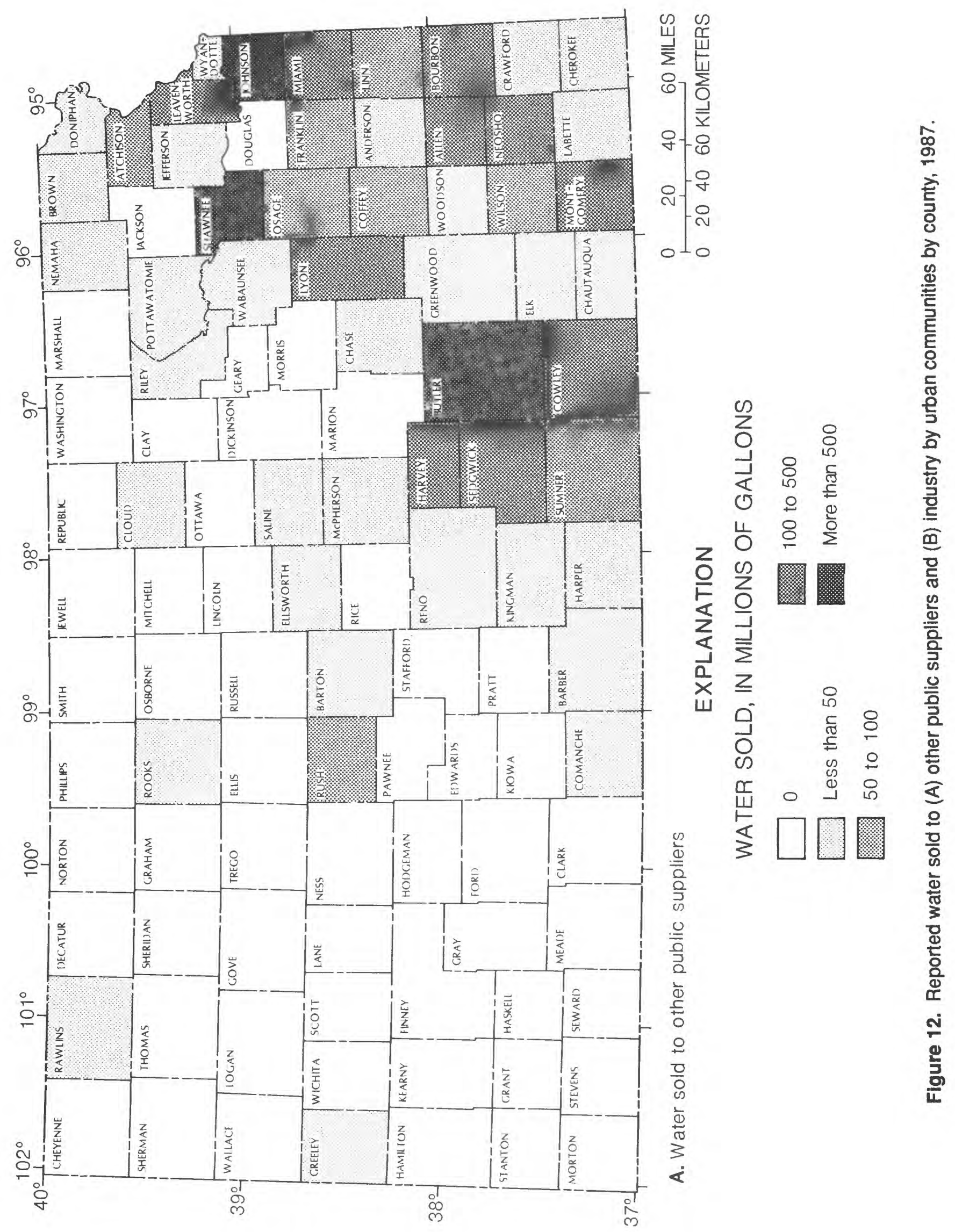




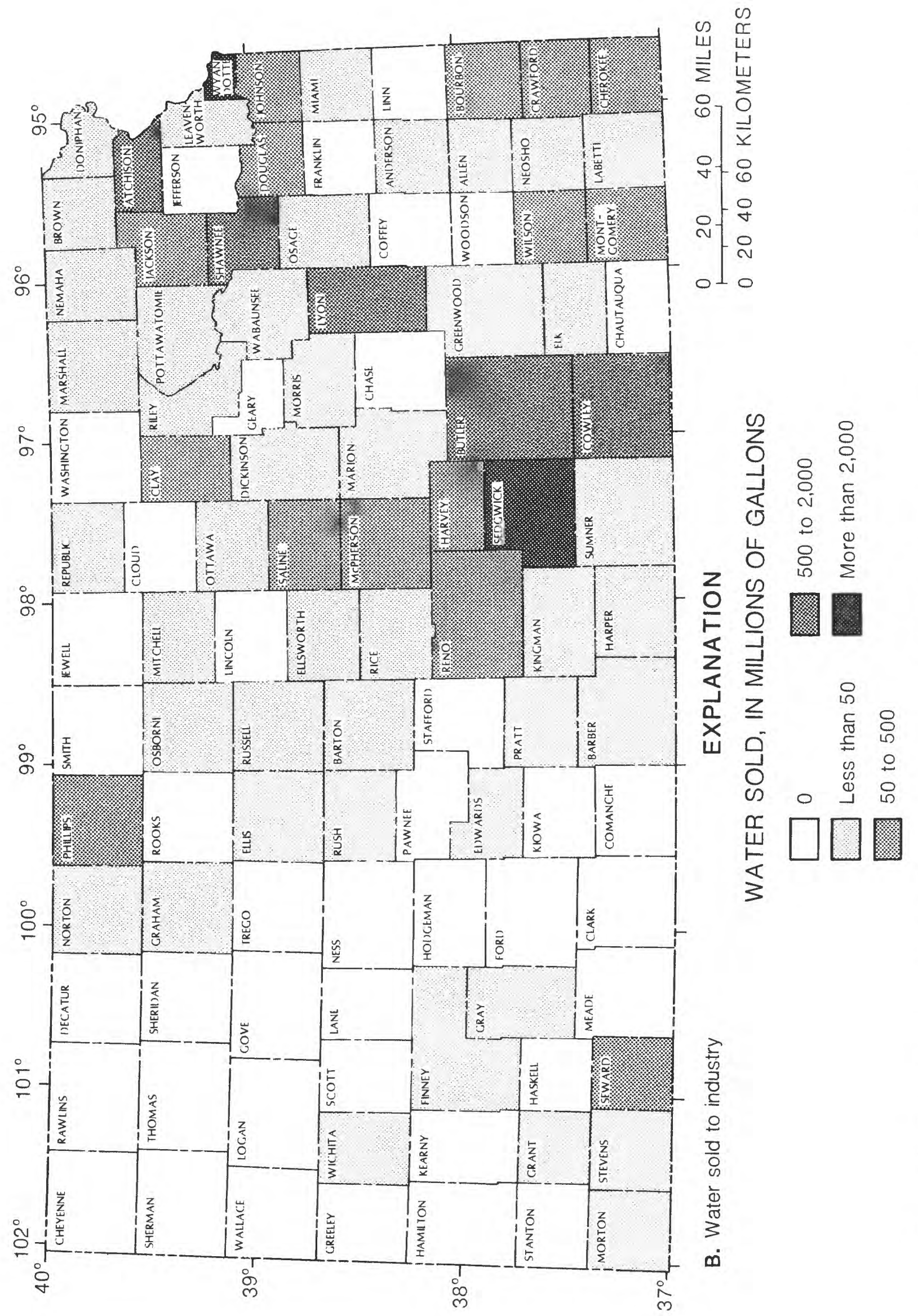

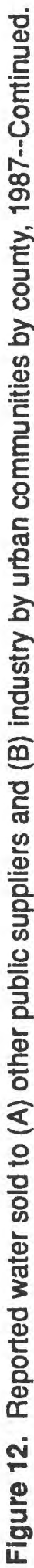




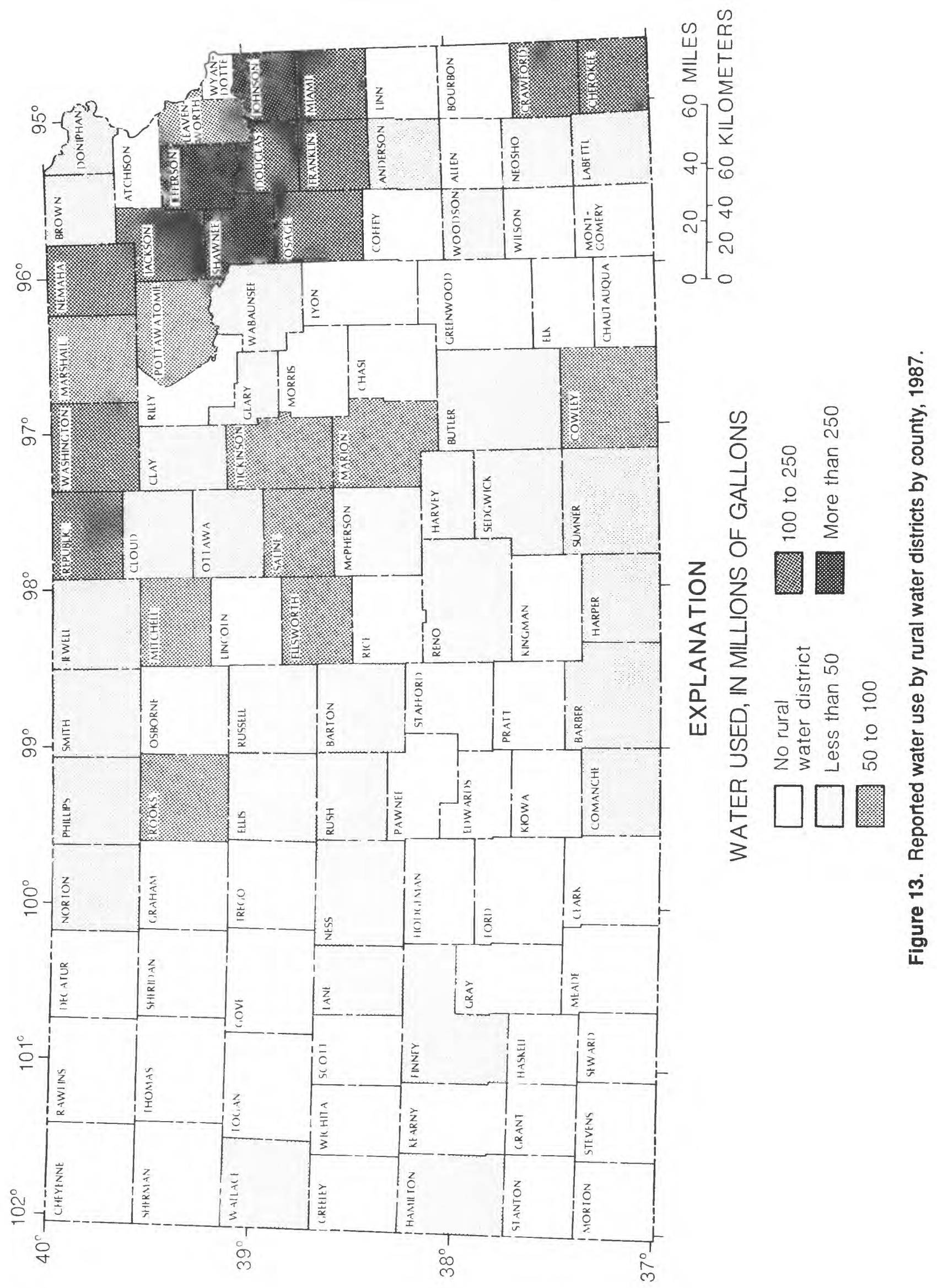




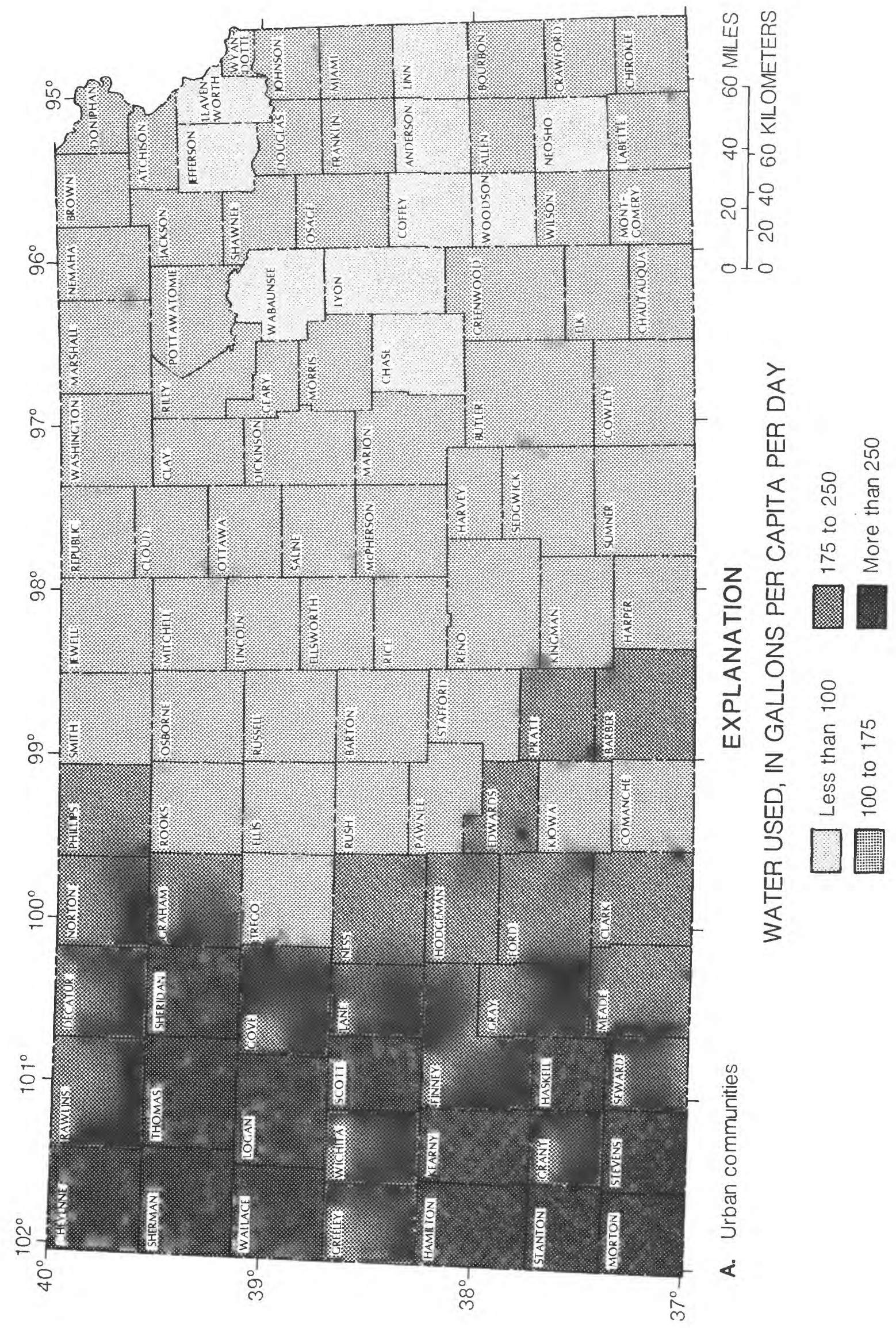




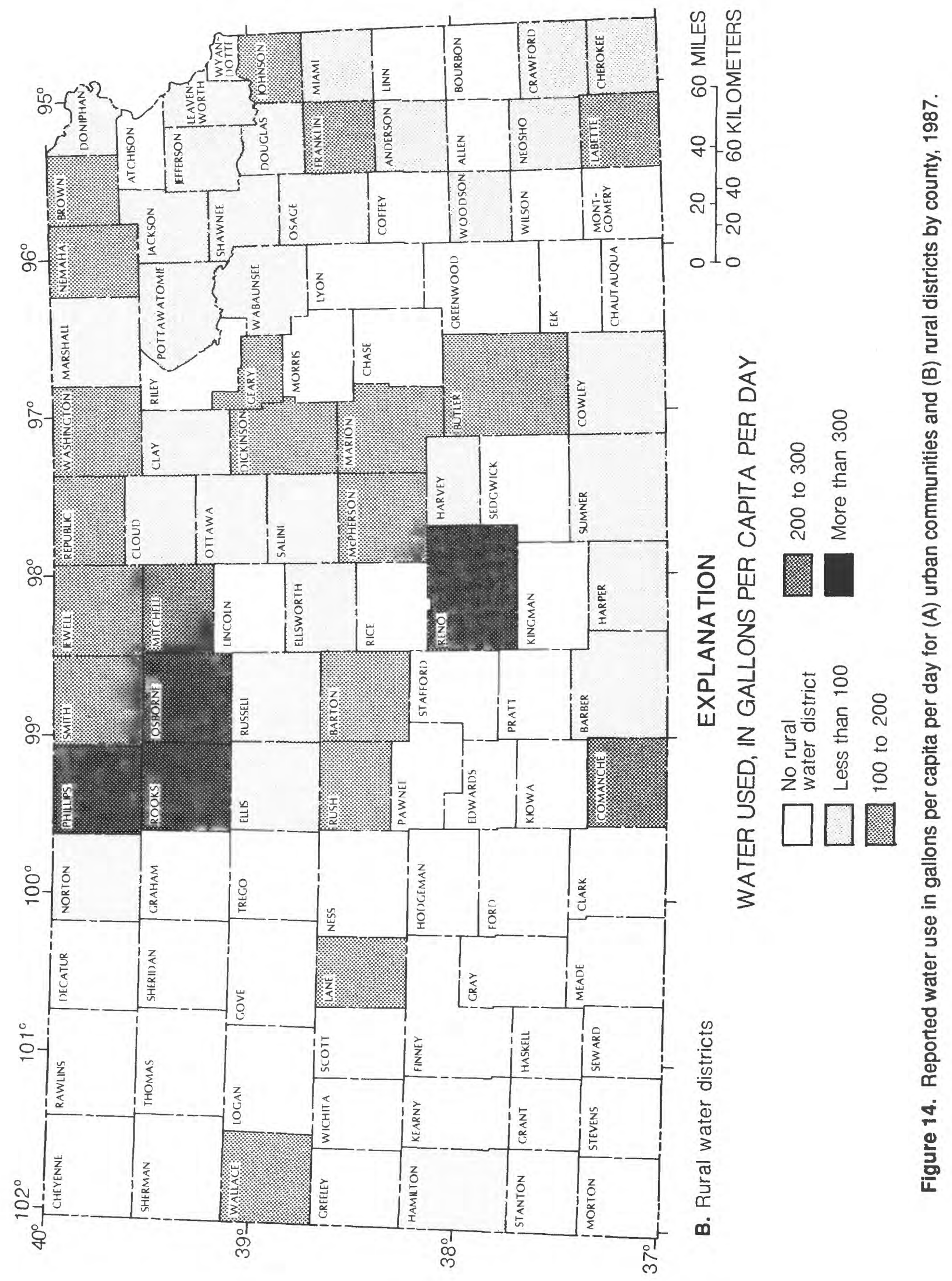


were calculated by using those water-use reports on which population was given (94 percent of urban-community reports, 95 percent of rural-water-district reports).

\section{Industrial}

\section{Diversions}

Industrial water use in Kansas is defined as “***the use of water in connection with the manufacture, production, transport or storage of products, or the use of water in connection with providing commercial services including water used in connection with steam electric power plants, secondary and tertiary oil recovery, air conditioning, heat pumps, hotels and motels***” [KSBA-DWR, 1983, sec. 5-1-1(n)]. Abount 30 percent of all industrial water use in Kansas is supplied by municipalities; the remainder is self-supplied and requires a water right. For this report, self-supplied industrial use was separated into two categories: (1) industrial and (2) thermoelectric power generation. Industrial water use includes all manufacturing and mining activities, plus minor amounts of commercial activity. Thermoelectric-powergeneration water use includes both fossil fuel and nuclear powerplants and will be discussed in a separate section of the report.

Water-use reports were sent to $\mathbf{5 1 5}$ industrial water users in 1987. Of this number, 168 reported no water use that year and 5 provided no water-use information. Total reported water diverted for self-supplied industrial uses for 1987 is shown by source in figure 15 and by county of withdrawal in figure 16; statewide these diversions totalled 30,622 Mgal. Surface-water diversions (fig. 17A) represented only about 8 percent of total industrial diversions and were located primarily in the eastern and south-central counties. Ground-water diversions (fig. 17B) were of much greater magnitude and were more evenly distributed throughout the State.

Use

As with municipal water rights, there are many water transfers among industrial users. Water may be sold to other users by the water-

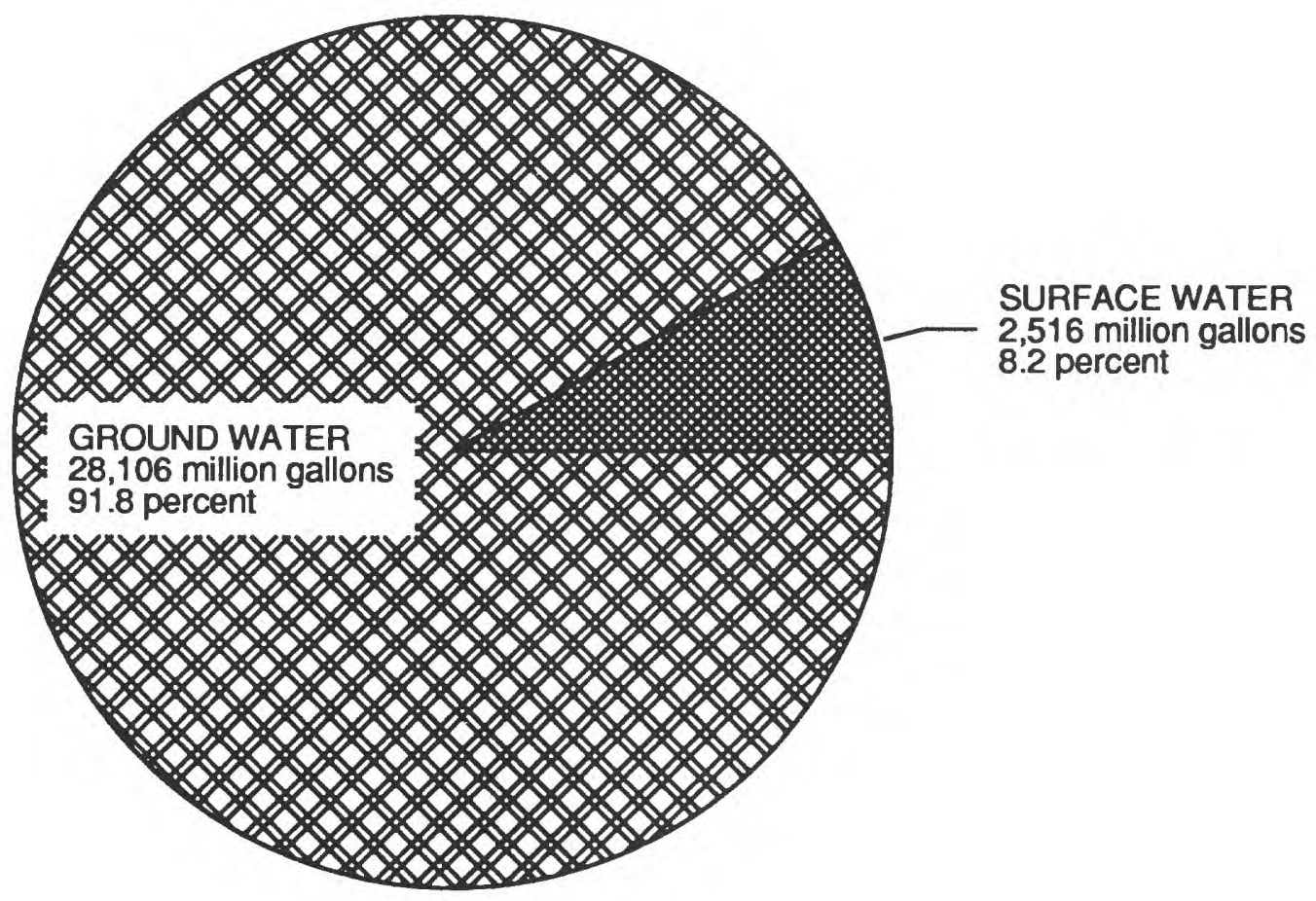

Figure 15. Reported water diversions for industrial use by source of supply, 1987. 


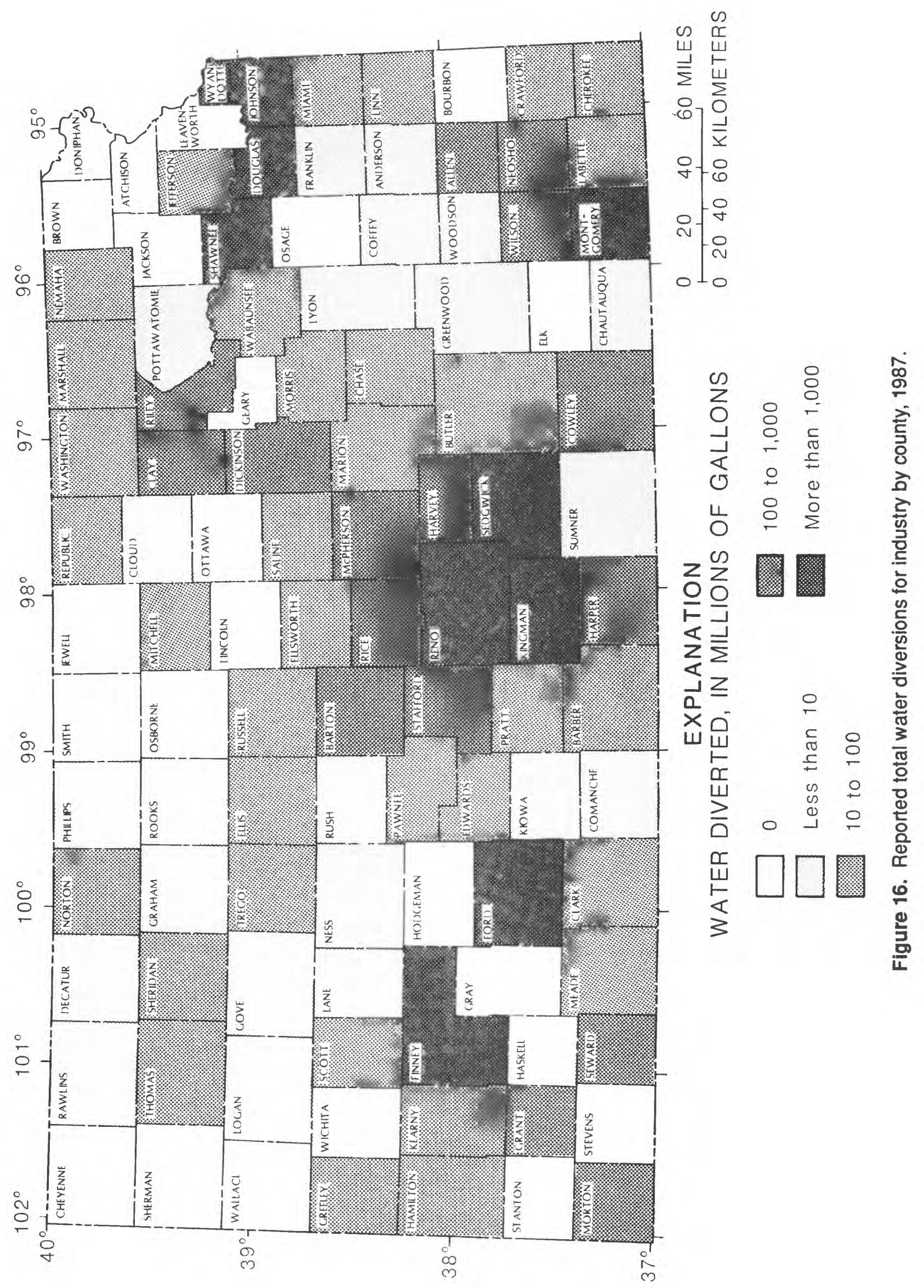




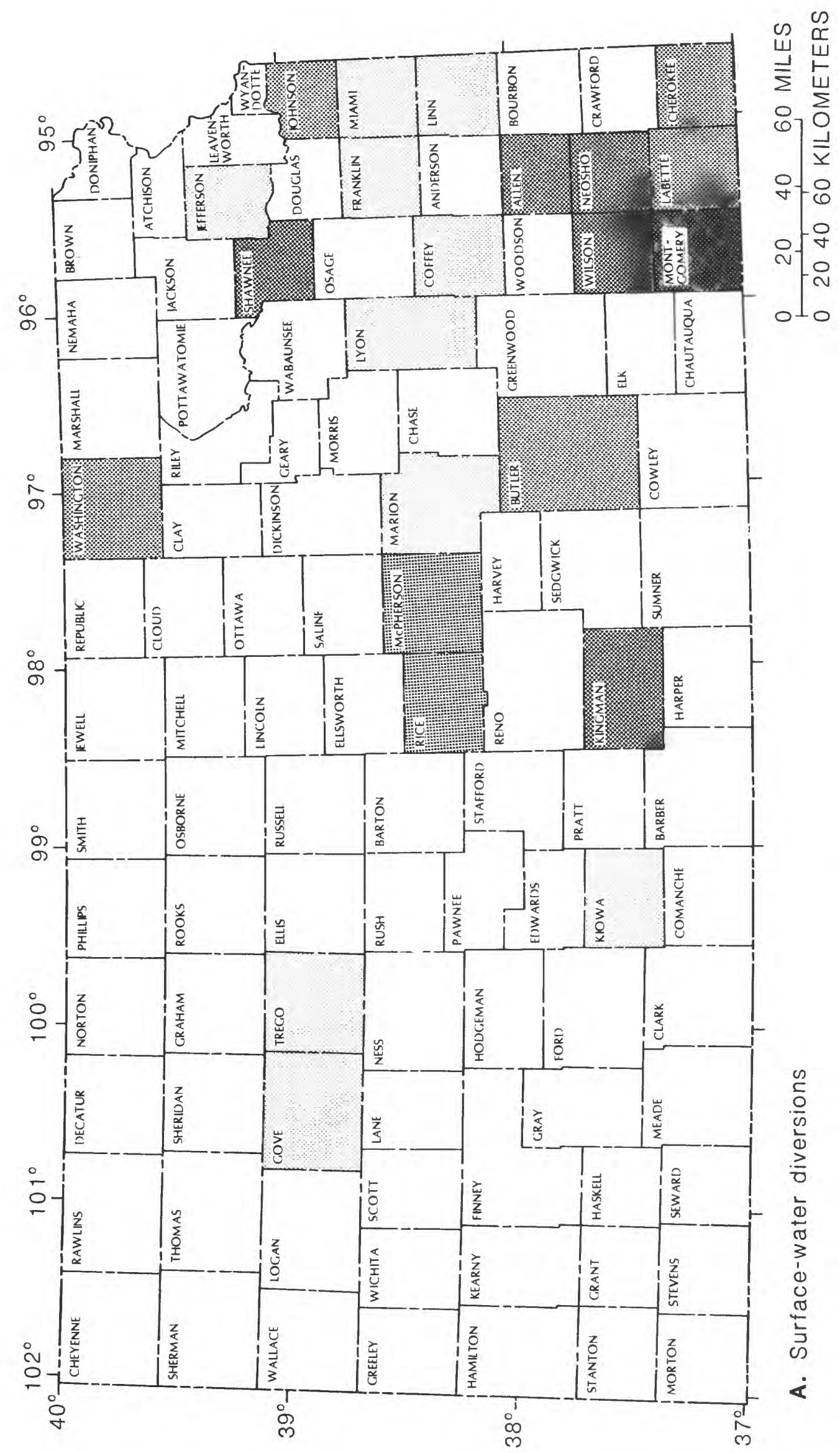




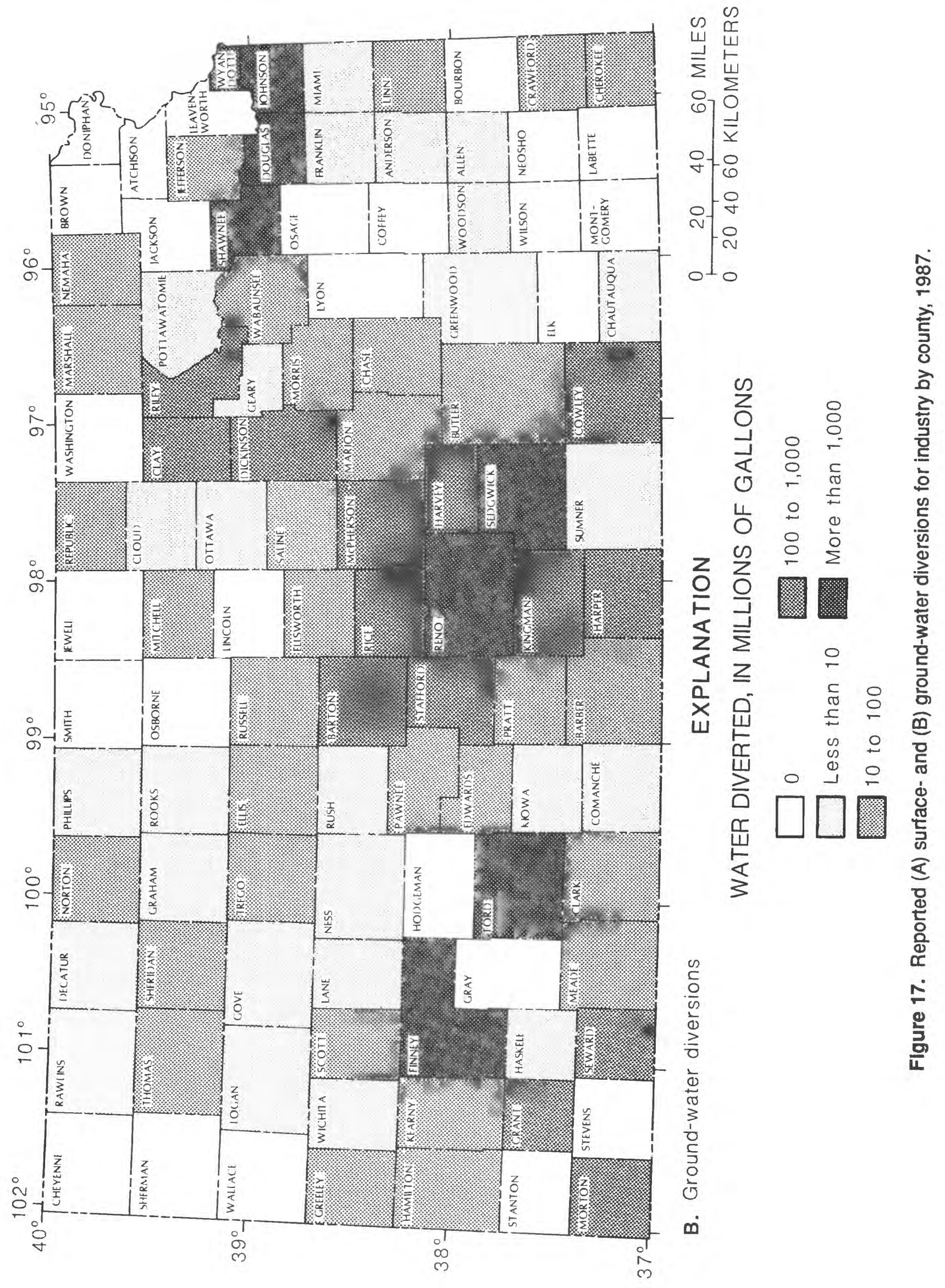


right holder who diverted it, or purchased from other municipal or industrial suppliers. In 1987 , 4,019 Mgal of water were reported purchased by industries with water rights; $270 \mathrm{Mgal}$ were reported sold by such entities. Total water use reported for all self-supplied industrial entities in 1987 was $34,397 \mathrm{Mgal}$ and is shown by county of use in figure 18. Intense water use in some counties was attributable to a few major types of industry: petroleum refining in Butler, Cowley, and Montgomery Counties; salt mining in Reno County; fertilizer production in Douglas and Ford Counties; and alcohol fuel production in Finney County. Large quantities of water were used for aerospace and chemical industries, manufacturing, and sand dredging in the urban areas around Wichita in south-central Kansas and in the Topeka-Kansas City corridor along the Kansas River in northeast Kansas.

\section{Thermoelectric Power Generation}

\section{Diversions}

Thermoelectric power generation represents the second largest diversion of water in Kansas. In 1987, 25 powerplants with water rights reported diversions of $170,661 \mathrm{Mgal}$ (fig. 5). More than 98 percent of these diversions was from surface-water sources (fig. 19). Total diversions by county are shown in figure 20 . Surface-water diversions were reported in nine counties, as shown in figure 21A. Powerplants in Cherokee and Wyandotte Counties together accounted for 92 percent of the surface-water diversions reported for thermoelectric power generation. Large quantities of surface water also were withdrawn for coal-fired powerplants in Douglas and Pottawatomie Counties and for the State's only nuclear powerplant in Coffey County. Ground-water diversions for thermoelectric power generation were reported in 11 counties, as shown in figure 21B. The largest ground-water withdrawals for this use occurred in Sedgwick County.

\section{Use}

Diversions of 170,661 Mgal for thermoelectric power generation in 1987 were supplemented by purchases of $250 \mathrm{Mgal} ; 153$ Mgal were sold. Resulting reported water use was thus $170,758 \mathrm{Mgal}$. Most of this amount
(90.6 percent) was nonconsumptive flowthrough at powerplants in Cherokee and Wyandotte Counties (fig. 22). At the Empire District Plant in Cherokee County, 4.88 percent of the total diversion from a storage lake on the Spring River was considered in 1987 by the DWR to be consumptive use. For Kansas City Board of Public Utilities in Wyandotte County, consumptive use was calculated as 0.015 percent of the total water withdrawal from the Kansas and Missouri Rivers. No formulas were available for computing consumptive use in 1987 at other powerplants in Kansas where flow-through is not a significant component of diversions. The 16,063 Mgal shown as consumptive use for thermoelectric power generation in figure 22 typically were used for evaportative-cooling needs. This quantity of water is the sum of diversions and purchases minus sales and significant nonconsumptive use, and is shown by county of use in figure 23 .

\section{Irrigation}

In Kansas, irrigation water-use permits are granted for “***the use of water for the growing of crops and the watering of lawns, golf courses, and parks***" [KSBA-DWR, 1983, sec. 5-1-1(o)]. Reports were sent to 11,858 water users for reporting 1987 water use; about 97 percent of these were returned to the DWR. Irrigated agriculture is by far the largest use of water in the State, representing about 80 percent of all reported diversions for all uses in 1987 (fig. 5). Diversions for irrigation that year totalled 1,403,122 Mgal, or 4.3 million acre-feet. Reported total diversions for irrigation are shown by source in figure 24 , and by county of withdrawal in figure 25. Reported surface-water diversions totalled $81,771 \mathrm{Mgal}$, or about 251,000 acre-feet; reported ground-water diversions totalled 1,321,351 $\mathrm{Mgal}$, or about 4.06 million acre-feet. Irrigation in eastern Kansas is most commonly from surface-water sources (fig. 26A), such as streams and reservoirs. The largest irrigation diversions, however, are from ground-water sources in western and south-central Kansas (fig. 26B), where the High Plains, Great Plains, and alluvial aquifers are pumped intensively for irrigating large acreages. 


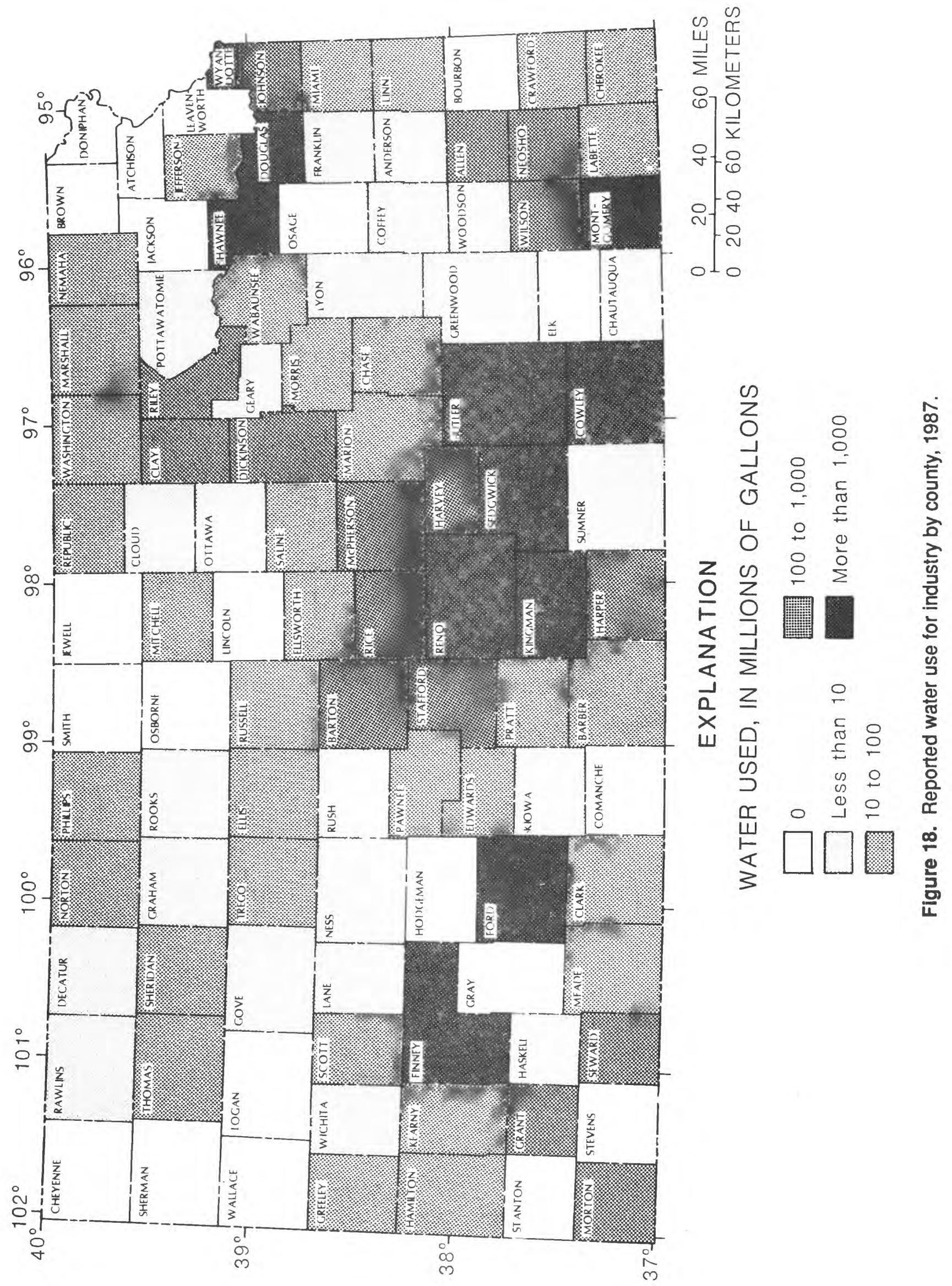




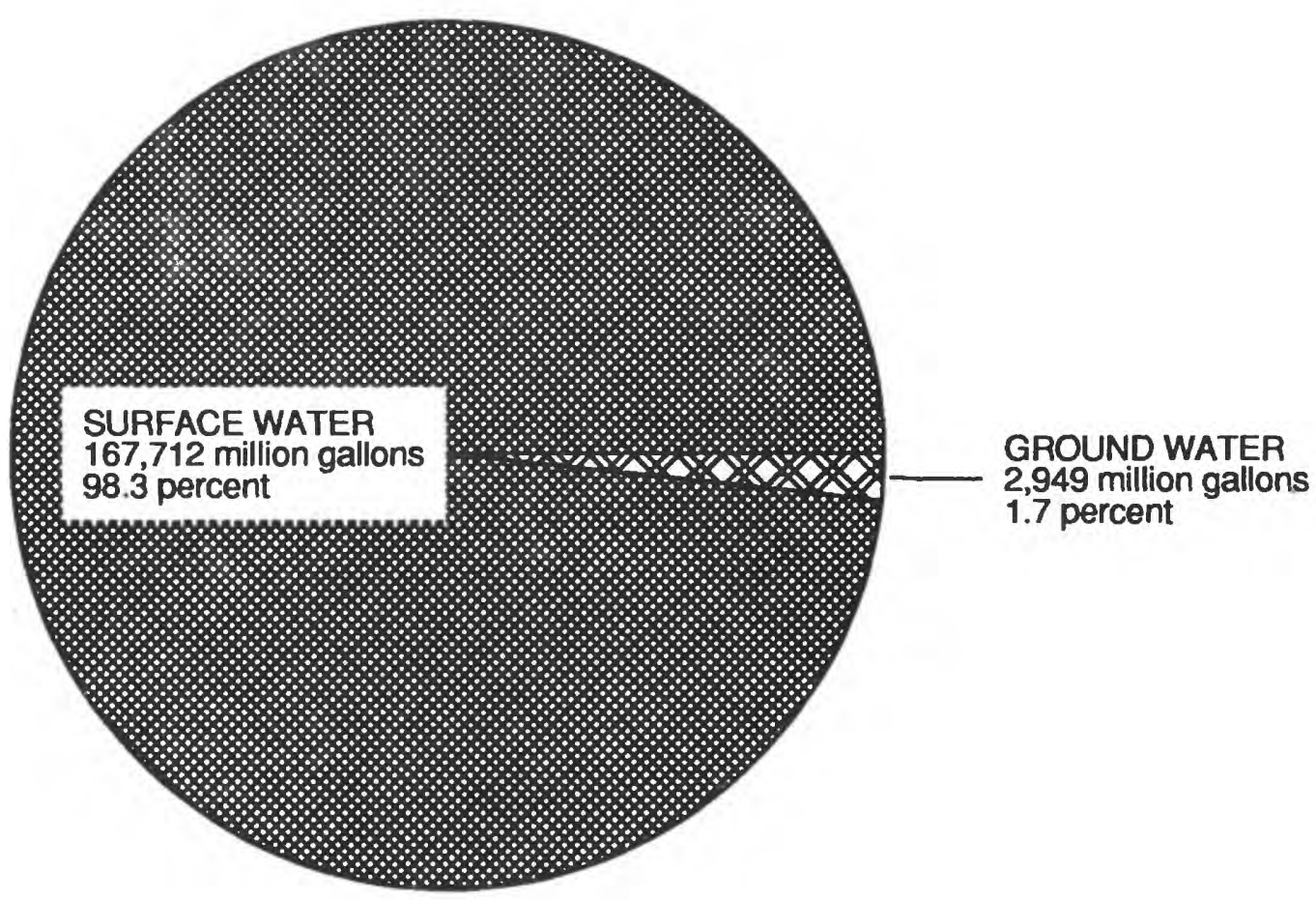

Figure 19. Reported water diversions for thermoelectric power generation by source of supply, 1987.

\section{Stockwatering}

Water needed for the raising of livestock has long been an important use of the resource in Kansas. Water rights are required for $" * * *$ the use of water for the watering of livestock and other uses of water directly related to the operation of a commercial feedlot required to be licensed by the Kansas livestock commission. That such use shall not include the irrigation of feed grains or other crops***” [KSBS-DWR, 1983, sec. 5-1-1(x)]. This definition only applies to feedlots of more than 1,000 head of livestock; other livestock watering is included as part of domestic or rural-water-district use. Stock watering diversions totalled 7,946 $\mathrm{Mgal}$ in 1987 and were almost entirely from groundwater sources (fig. 27). These diversions are shown by county in figure 28. The largest diversions for stockwatering occurred in counties in western Kansas; surface-water diversions occurred mostly in counties in eastern Kansas.

\section{Recreation}

According to the DWR, water rights in the recreation category are issued for uses of water that provide ${ }^{\mu * * * *}$ entertainment, enjoyment, and relaxation" [KSBA, DWR, sec. 5-1-1(v)]. This broad definition includes water rights for such diverse activities as maintaining water levels in lakes, fishing ponds, and golf-course hazards. Consequently, many of the reported water diversions for recreation are used to offset evaporative losses. These diversions totalled 28,709 Mgal in 1987 and were primarily from surface-water sources (fig. 29). Counties reporting recreation water diversions in 1987 are shown in figure 30. 


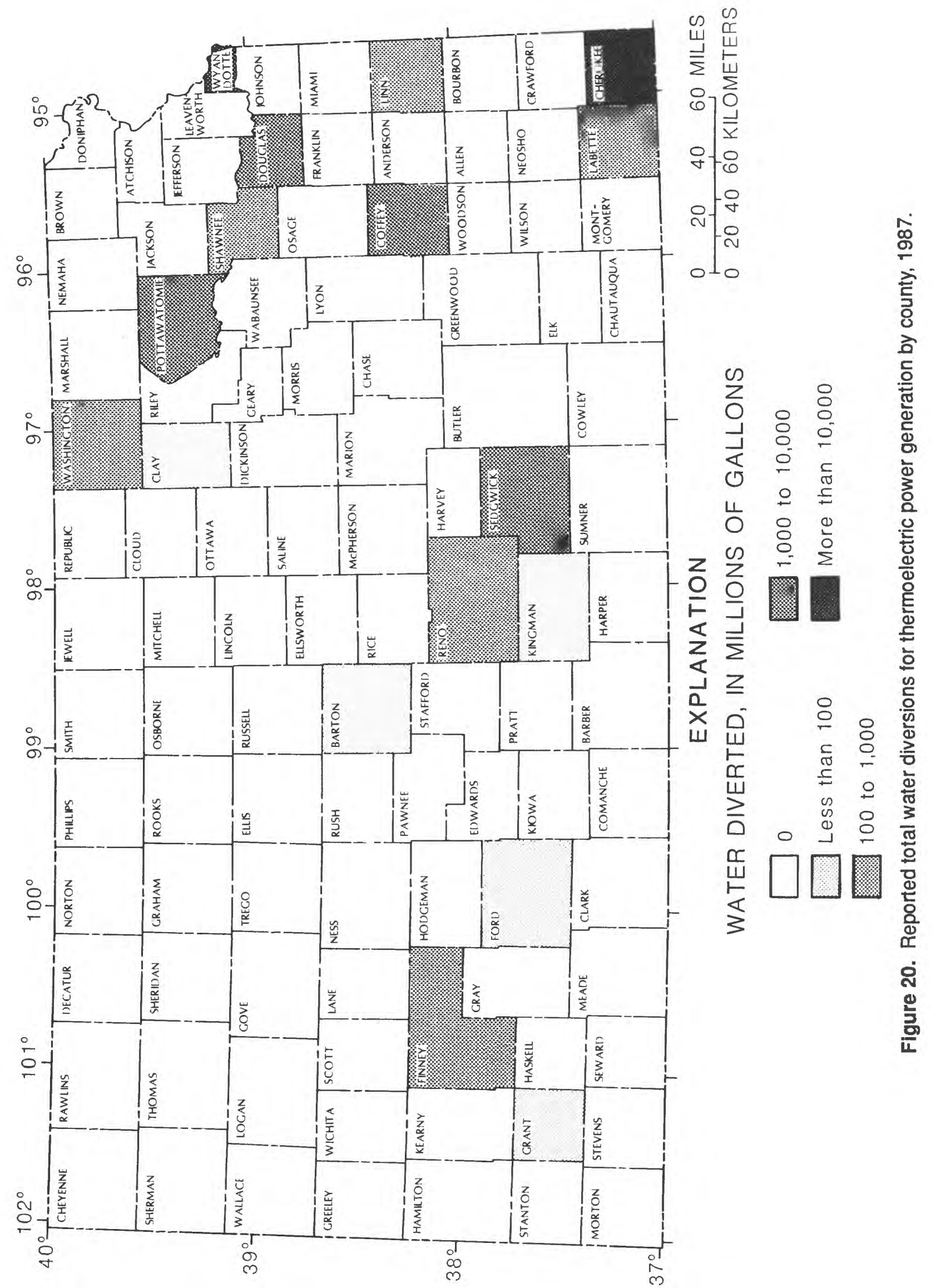




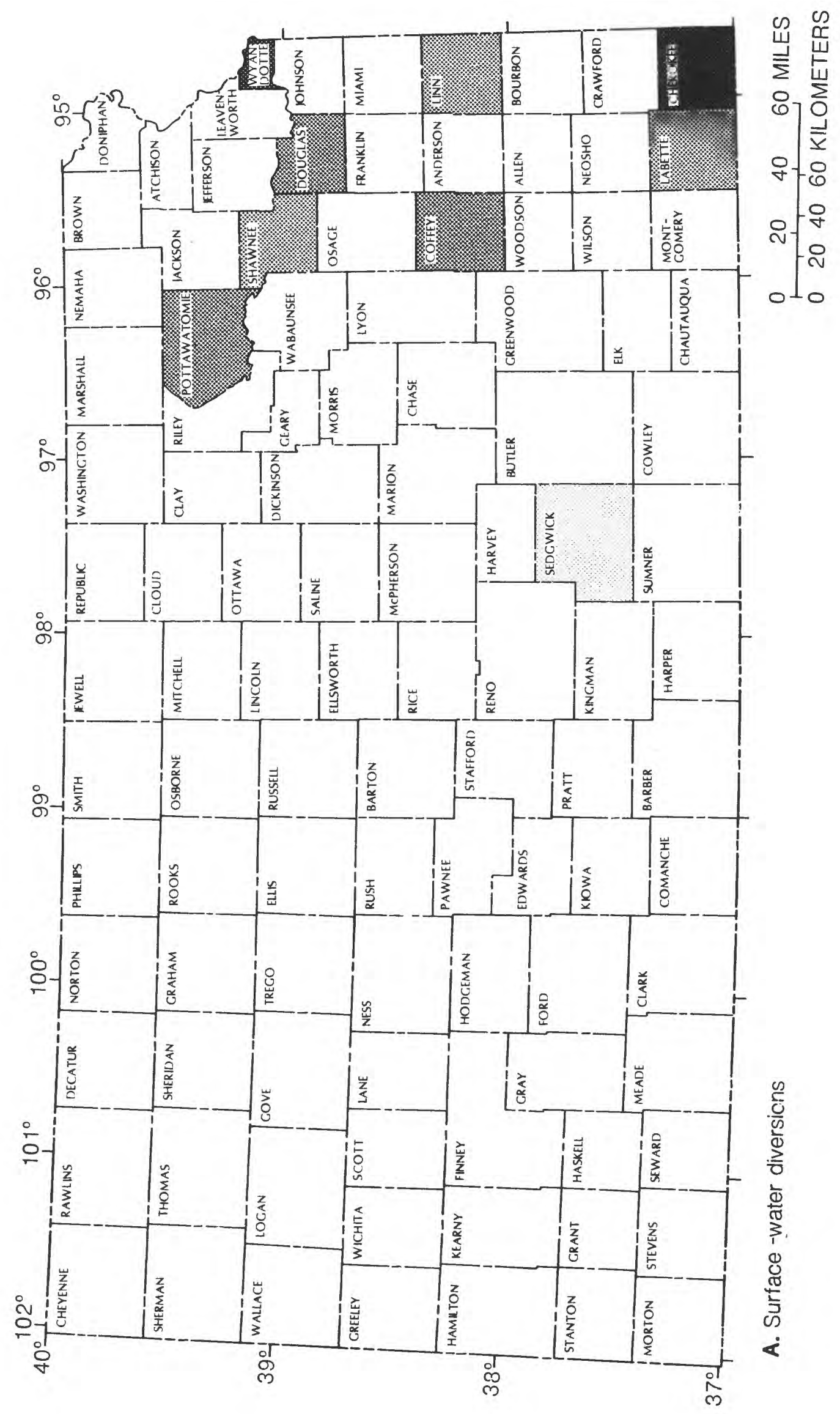




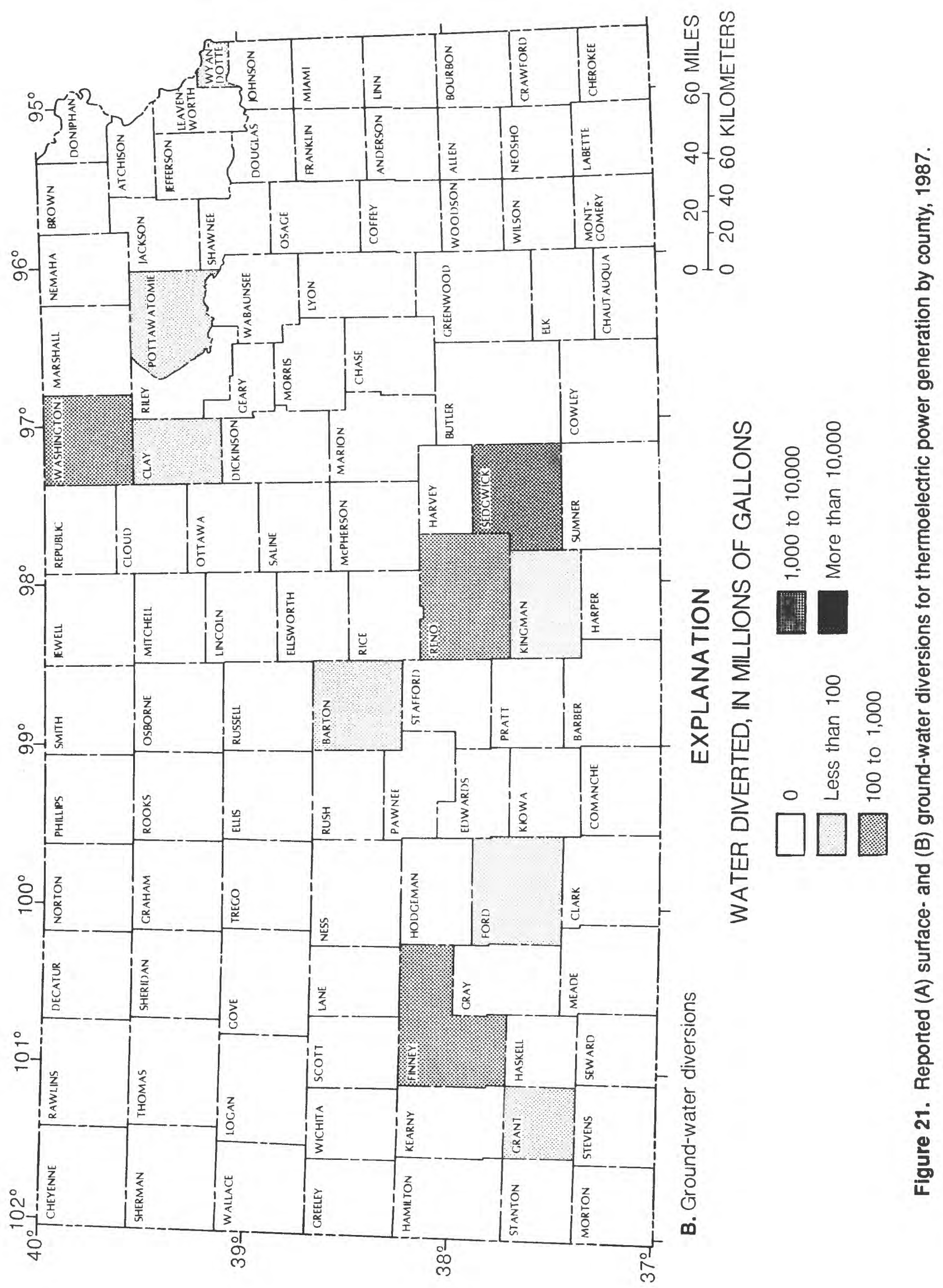




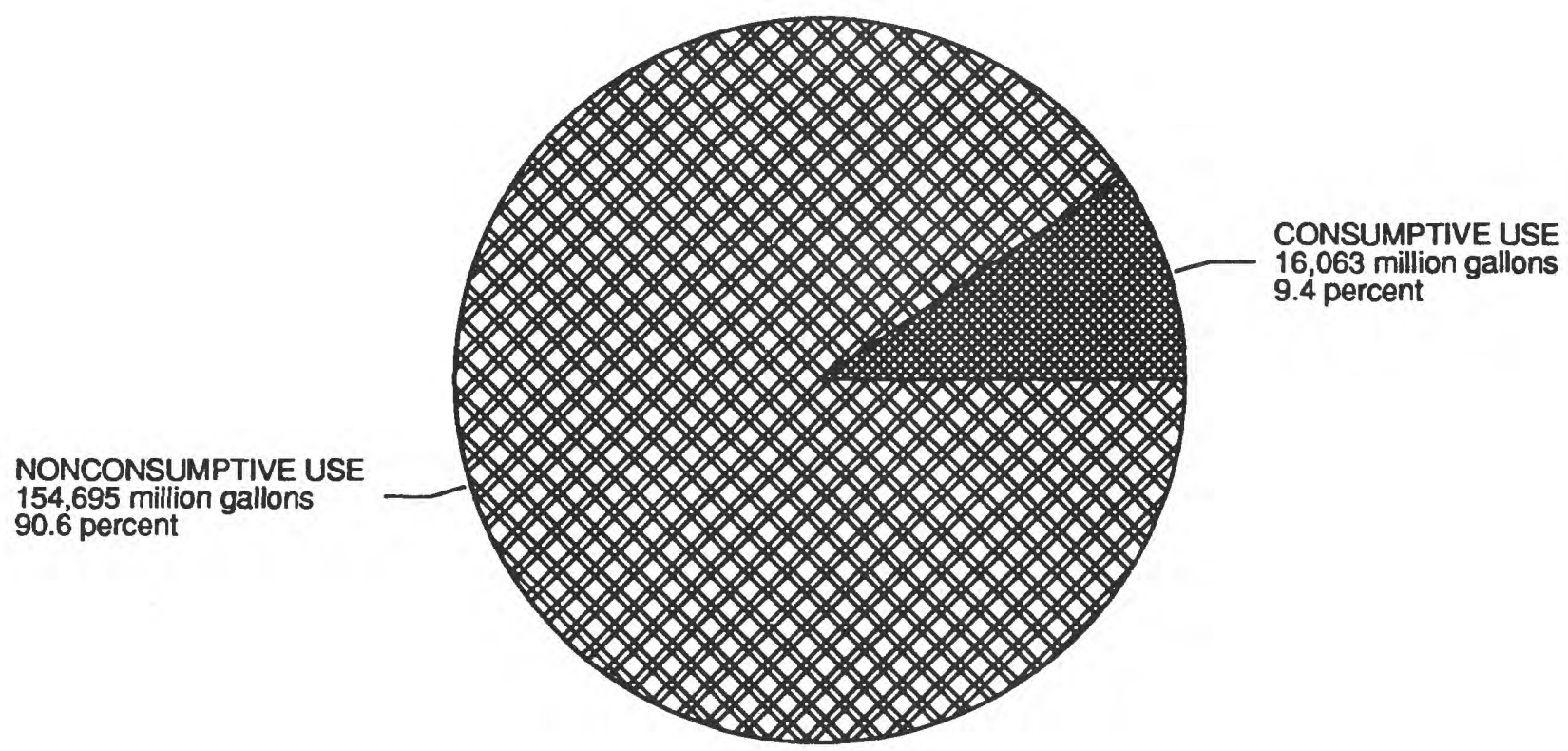

Figure 22. Consumptive and nonconsumptive water use for thermoelectric power generation, 1987.

\section{SUMMARY}

Water-use data for all authorized beneficial uses are reported annually to the Kansas State Board of Agriculture, Division of Water Resources, as required by amendments to the 1945 Water Appropriation Act. These data are provided by water users and include different types of information depending on the category of water use. All water-use reports indicate surface- and ground-water diversions for the previous year. Reports for municipal, industrial, and power-generation water uses also include information on purchases, sales, and use of water. This allows presentation of water withdrawals by point of diversion and water use by location of the user. Data from most cities and rural water districts include the population served, allowing computation of per capita consumption.

A total of $1,760,658 \mathrm{Mgal}$ was reported diverted in Kansas in 1987. Withdrawals for irrigation represented 79.7 percent of this total; for thermoelectric power generation, 9.7 percent; and for municipal use, 6.8 percent. Reported withdrawals for domestic, industrial, stockwatering, and recreation uses accounted for the remaining 3.8 percent.
The sources of water for the various categories of use in Kansas vary with the type of use and the location of that use within the State. Ground water supplied 81 percent of the total water reported diverted in Kansas in 1987, due primarily to large ground-water withdrawals for irrigation. Most of the water diverted for domestic, industrial, and stockwatering uses in 1987 also was from ground water. Ground-water withdrawals for these uses were more common in the central and western parts of the State that are underlain by major aquifers.

Most of the water diverted for thermoelectric power generation and recreation in 1987 was surface water. These withdrawals occurred primarily in the eastern part of Kansas where surface water is readily available. Thermoelectric-power-generation water withdrawals, which accounted for $\mathbf{9 8}$ percent of all surface water diverted, were largely nonconsumptive.

Water for municipal use in 1987 was diverted about equally from surface- and ground-water sources. Surface-water diversions occurred primarily in the eastern one-third of Kansas, due to water availability and to locations of population centers. Ground water 


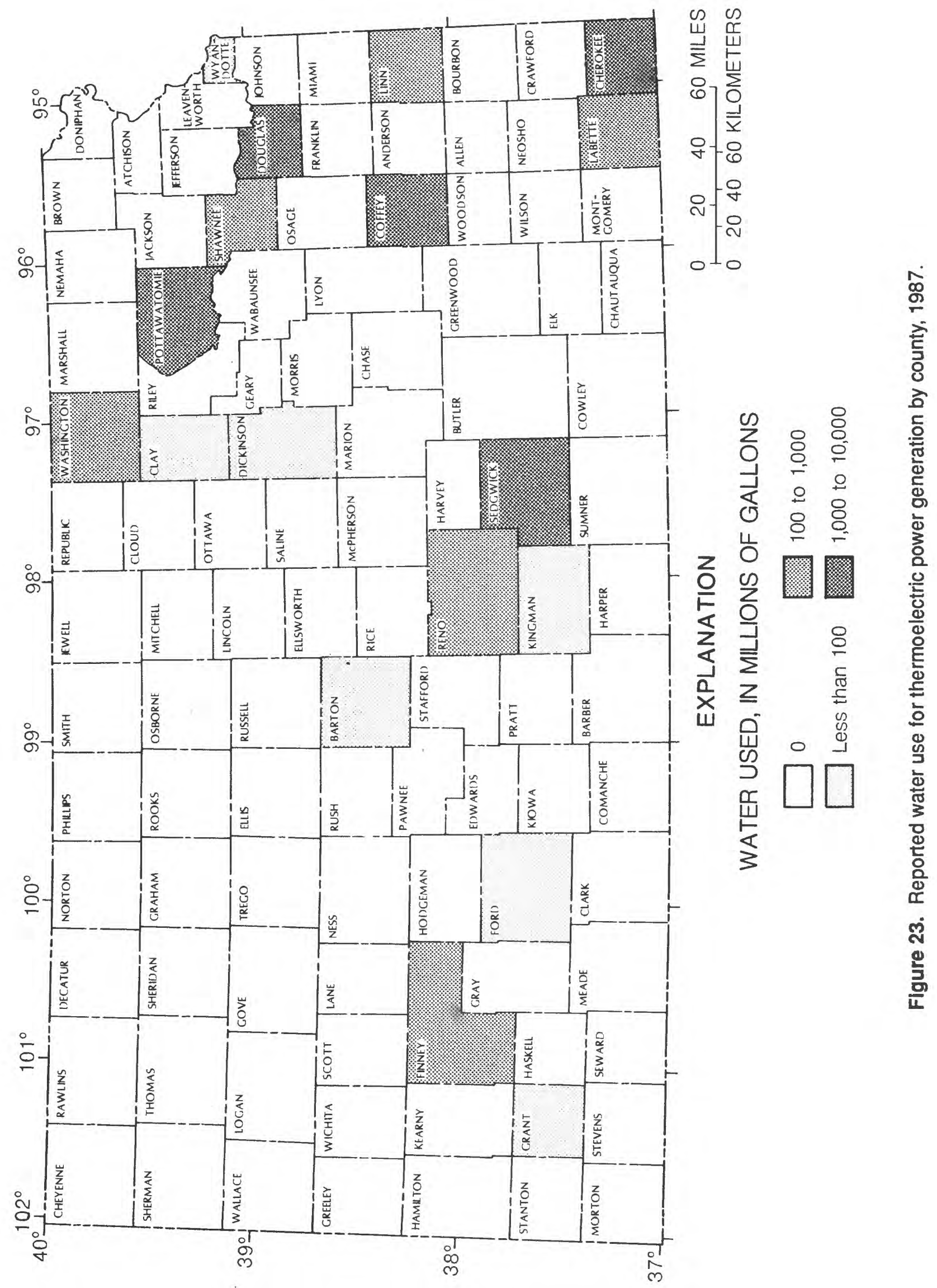




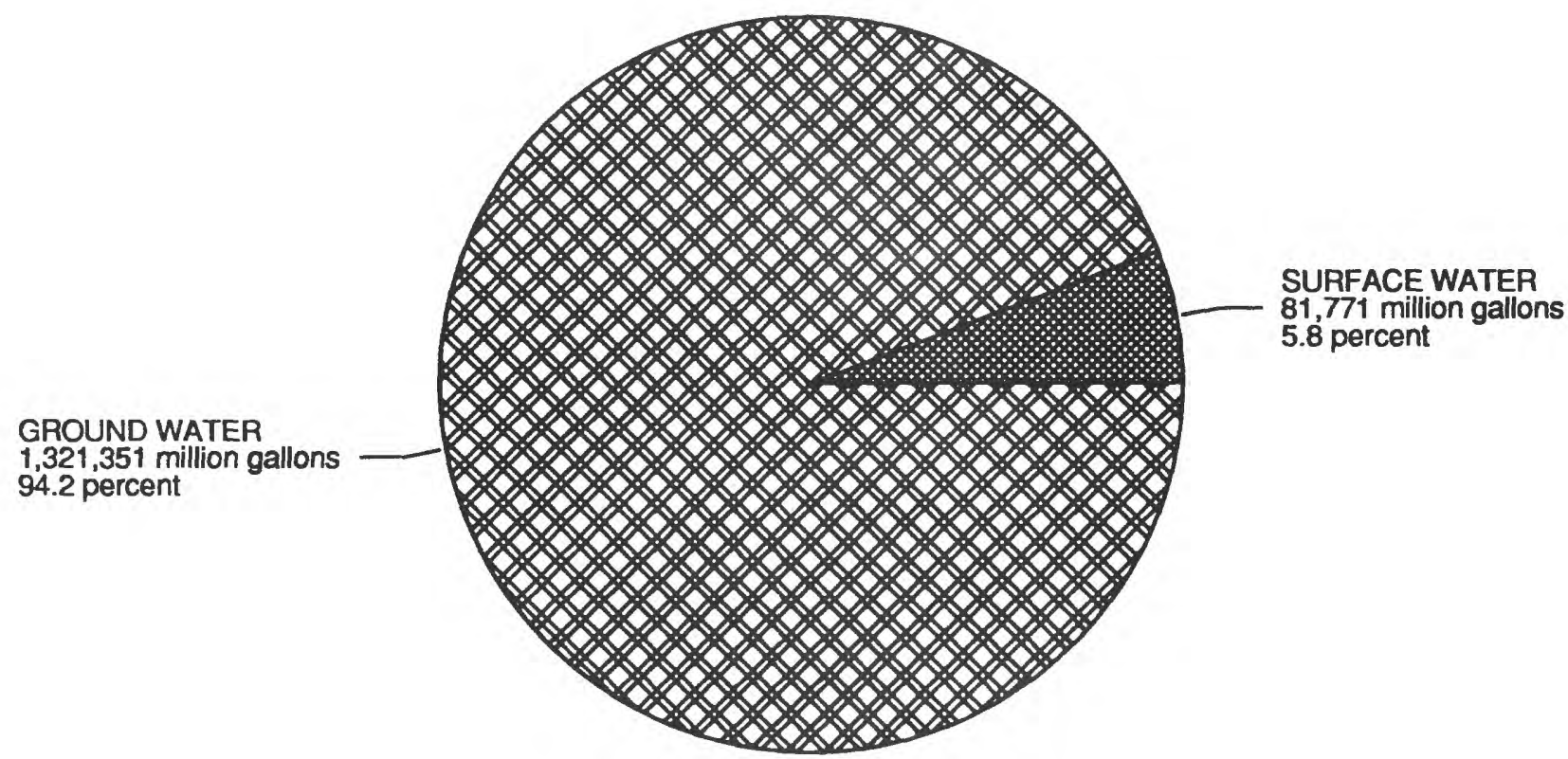

Figure 24. Reported water diversions for irrigation by source of supply, 1987.

was used for municipal supplies nearly everywhere in the State and was the only source of water for many areas in the western part. More water was used for municipal supplies in the populous eastern part of Kansas, but water use in gallons per capita per day was greater in the arid western part of the State.

\section{REFERENCES}

Bevans, H.E., Spruill, T.B., and Kenny, J.F., 1985, Kansas ground-water resources, in National Water Summary 1984--Hydrologic events, selected water-quality trends, and ground-water resources: U.S. Geological Survey Water-Supply Paper 2275, p. 217222.

Institute for Public Policy and Business Research, 1990, Kansas statistical abstract 1988-89: Lawrence, University of Kansas, $298 \mathrm{p}$.

Jordan, P.R., 1986, Kansas surface-water resources, in National Water Summary 1985--Hydrologic events and surface-water resources: U.S. Geological Survey WaterSupply Paper 2300, p. 237-244.
Kansas State Board of Agriculture, 1983, Rules and regulations, Water Appropriation Act: Topeka, Kansas, Division of Water Resources, 15 p.

Kansas Water Office, 1984, Kansas water supply and demand estimates: Topeka, Kansas, State Water Plan, Background Paper No. 15, 119 p.

Kansas Water Office and Kansas State Board of Agriculture, Division of Water Resources, 1988, 1987 Kansas municipalities water use: Topeka, $69 \mathrm{p}$.

Kenny, J.F., 1986, Water demands in Kansas, 1944-84: U.S. Geological Survey WaterResources Investigations Report 86-4038, 17 p.

Solley, W.B., Merk, C.F., and Pierce, R.R., 1988, Estimated use of water in the United States in 1985: U.S. Geological Survey Circular $1004,82 \mathrm{p}$.

U.S. Geological Survey, 1976, Hydrologic unit map--1974, State of Kansas: Reston, Va., scale $1: 500,000,1$ sheet. 


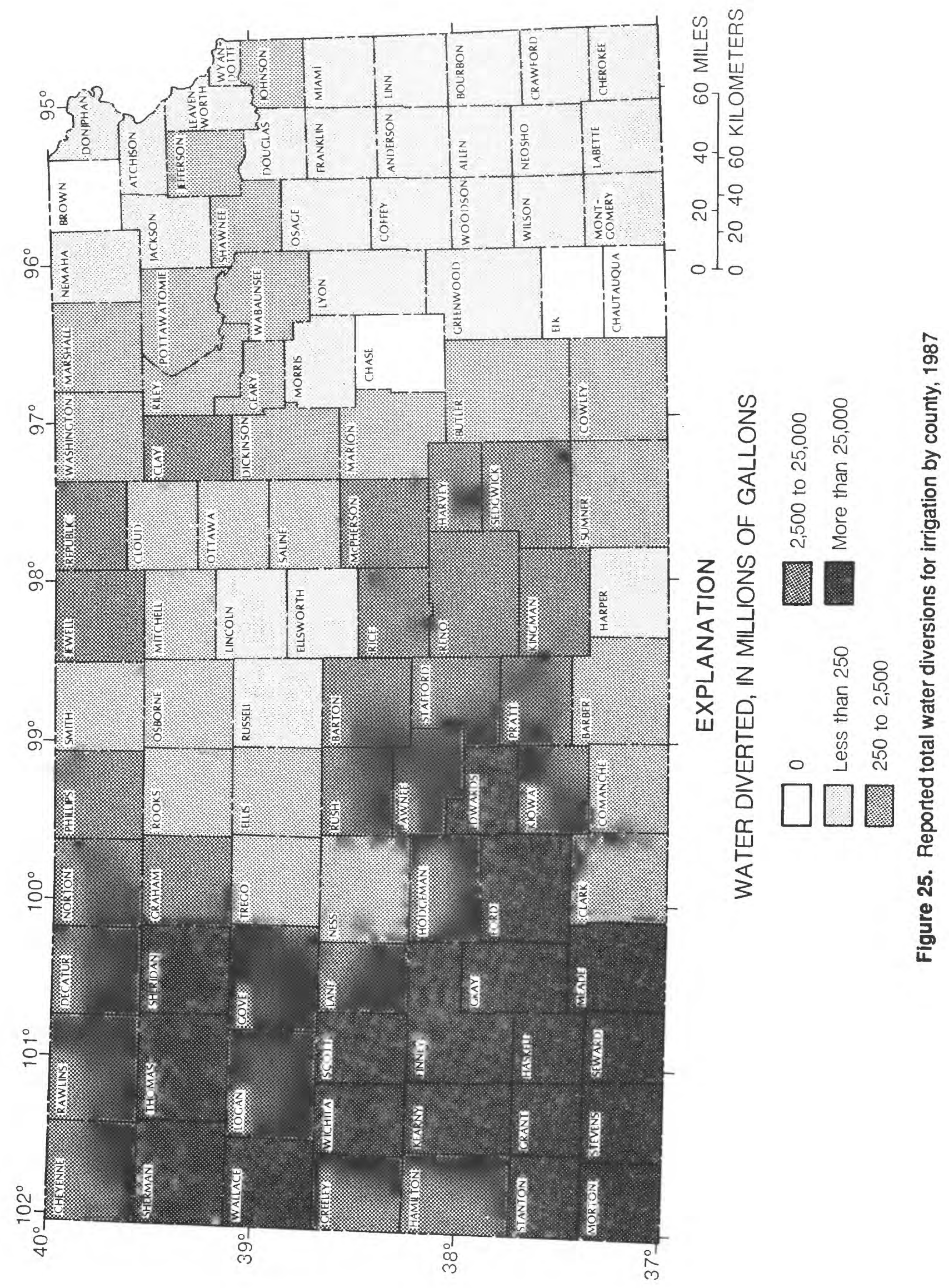




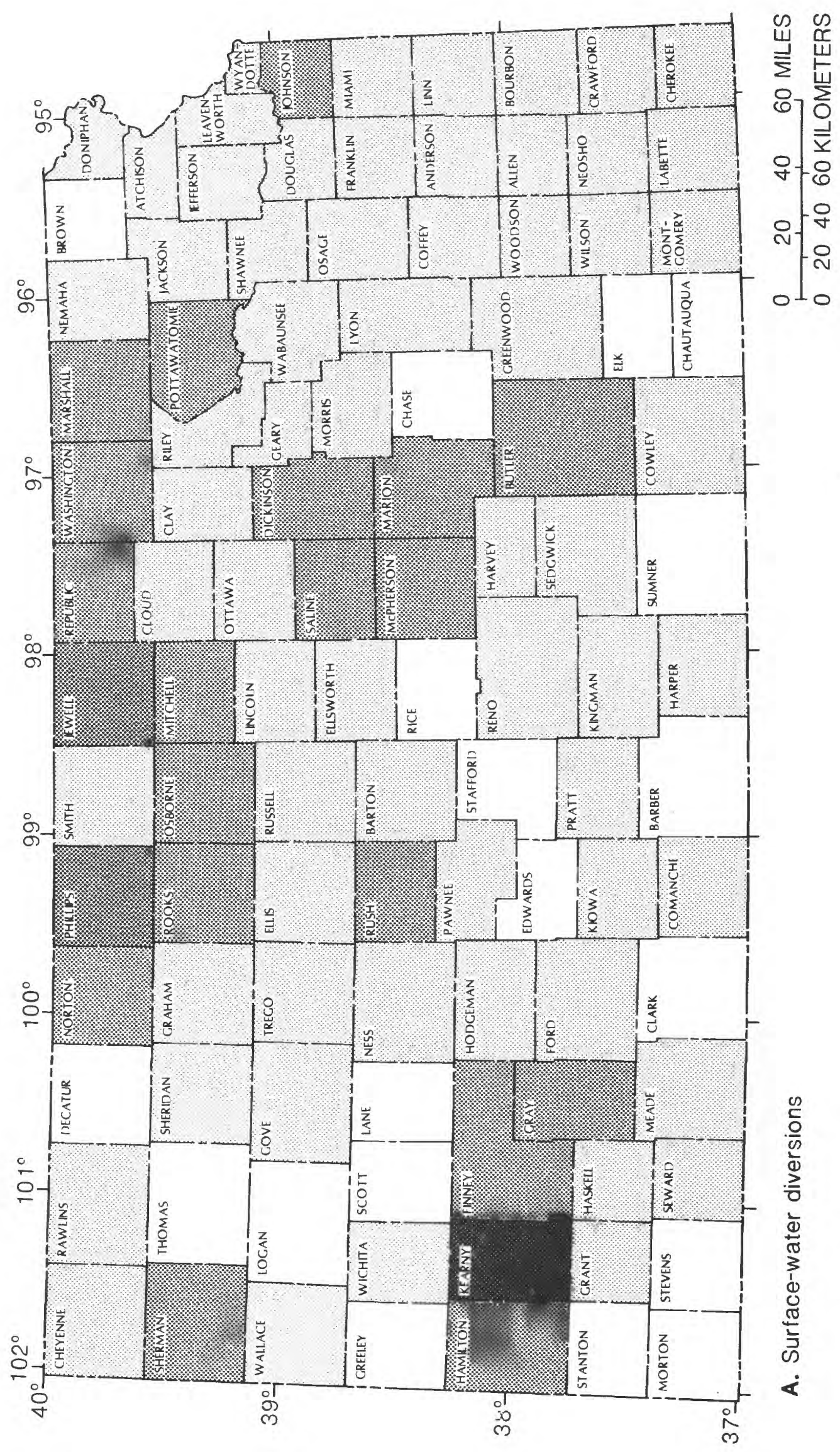




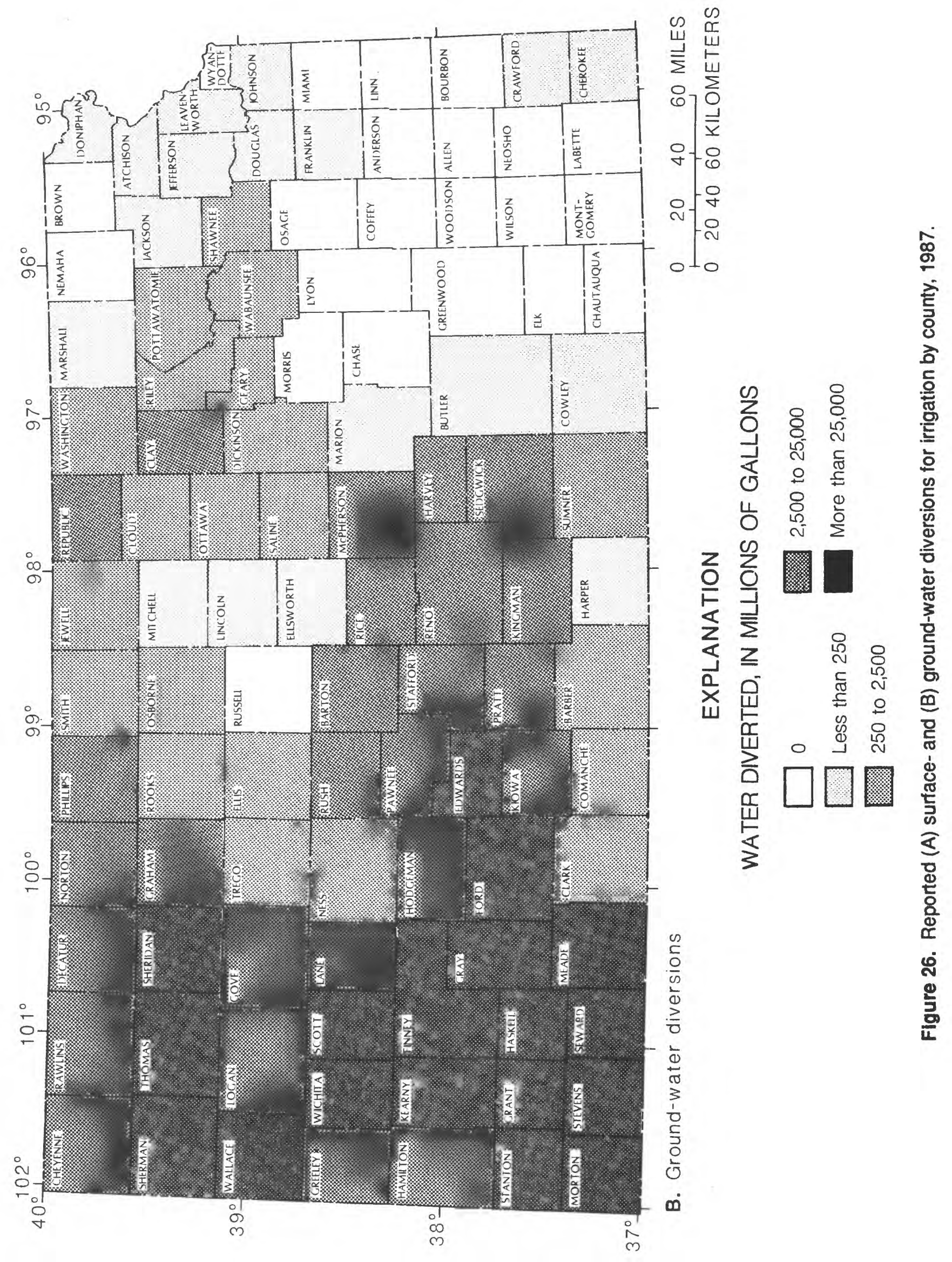




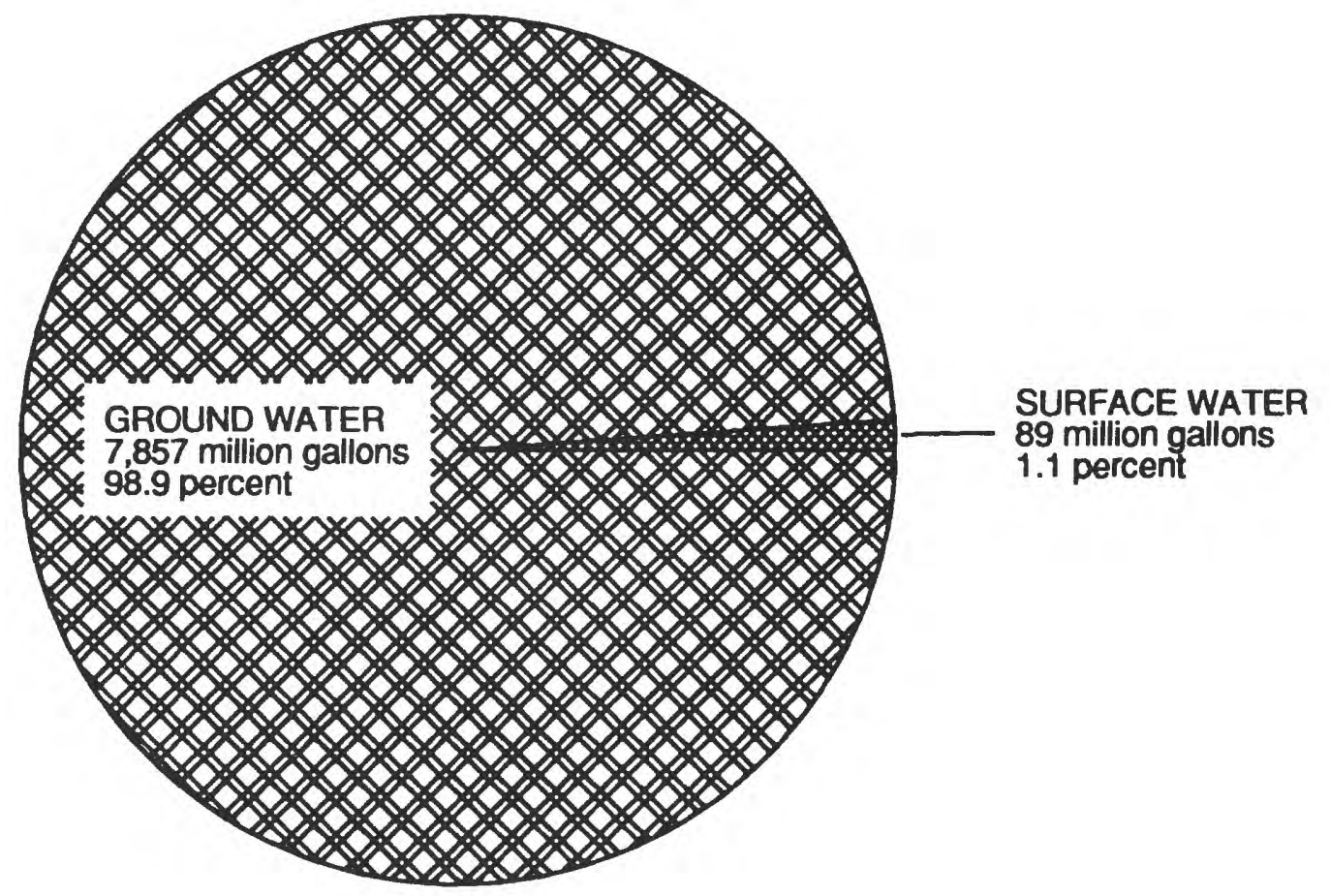

Figure 27. Reported water diversions for stockwatering by source of supply, 1987. 


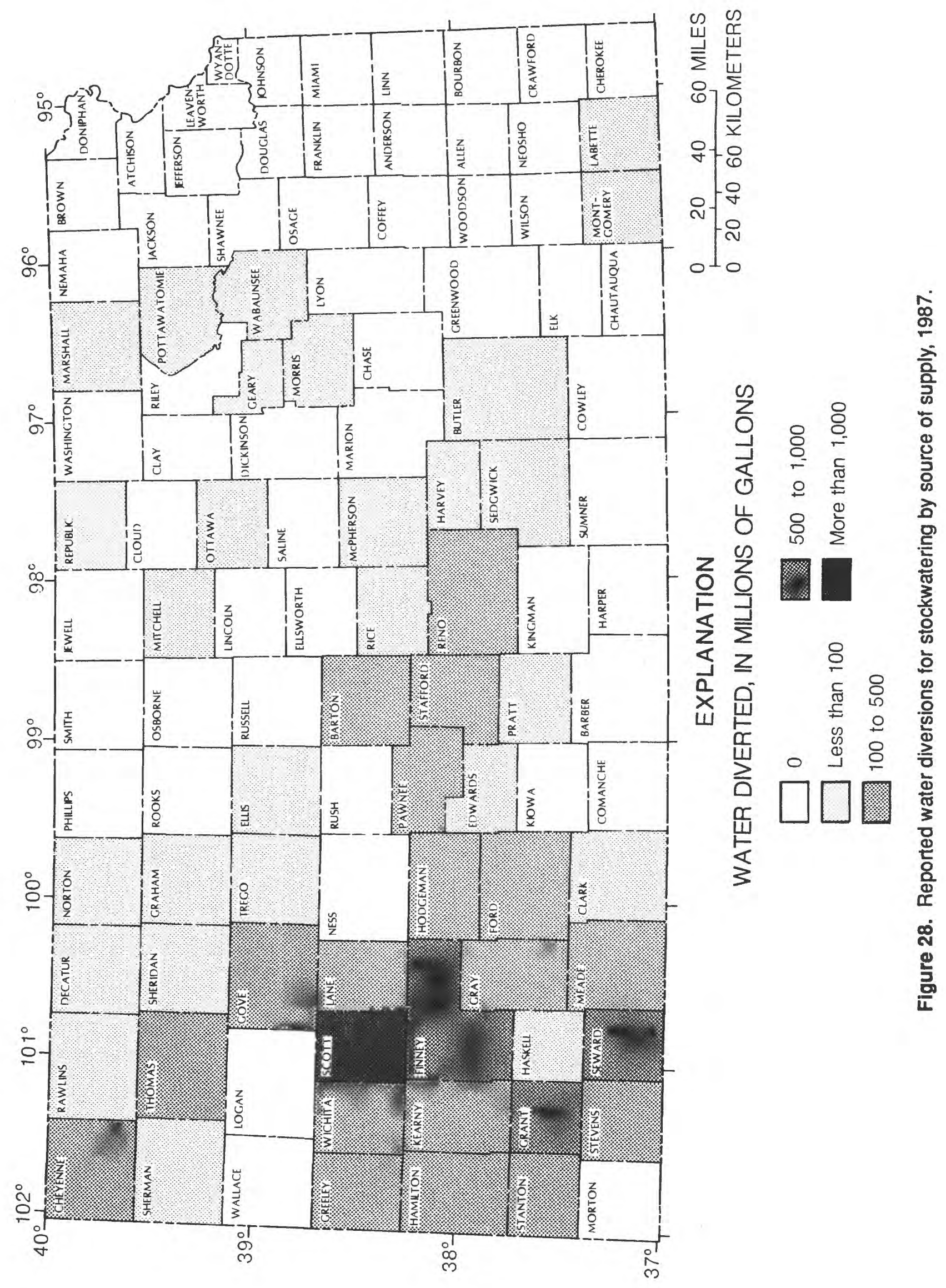




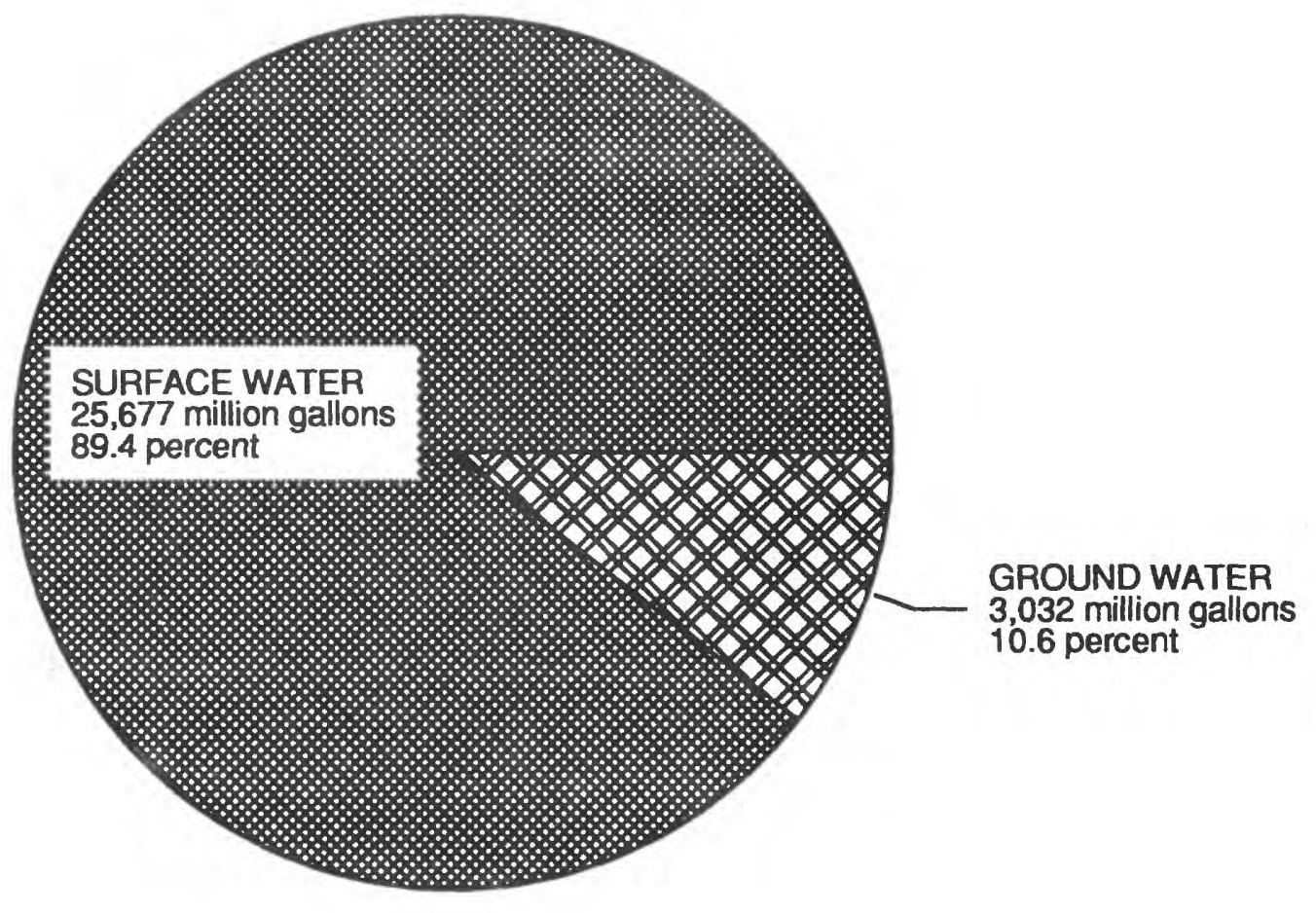

Figure 29. Reported water diversions for recreation by source of supply, 1987. 


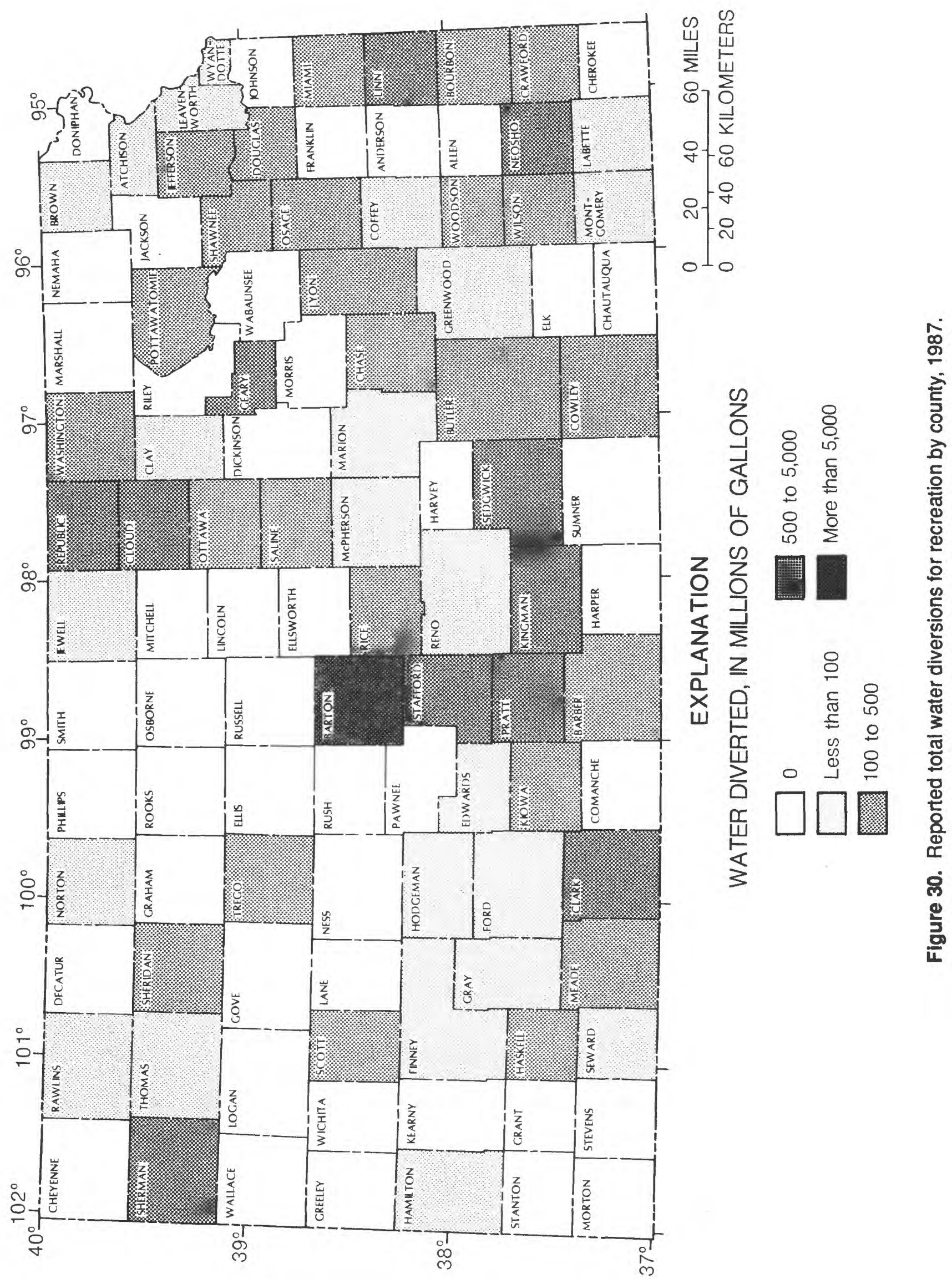

